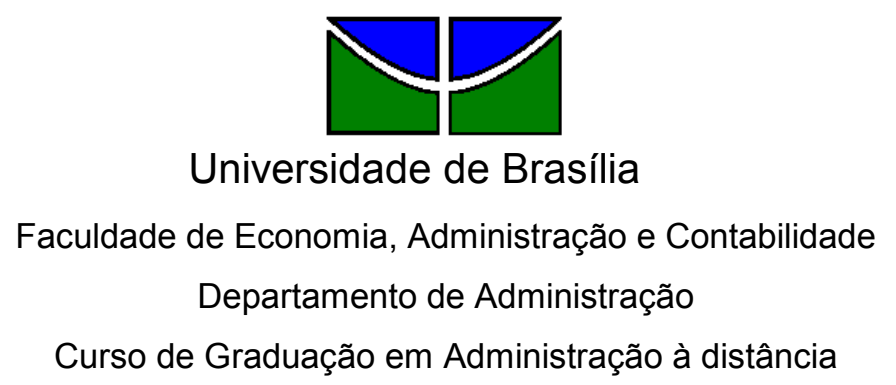

LEANDRO MARINHO PINHEIRO DE SOUSA

\title{
GESTÃO AMBIENTAL NO BANCO DO BRASIL: uma visão de agência
}

Brasília - DF 
LEANDRO MARINHO PINHEIRO DE SOUSA

\section{GESTÃO AMBIENTAL NO BANCO DO BRASIL: uma visão de agência}

Monografia apresentada a Universidade de Brasília (UnB) como requisito parcial para obtenção do grau de Bacharel em Administração.

Profa. Orientadora: Mestre Marta Eliza de Oliveira.

Brasília - DF 
Sousa, Leandro Marinho Pinheiro de Sousa.

Gestão Ambiental no Banco do Brasil: uma visão de agência / Leandro Marinho Pinheiro de Sousa. - Brasília, 2010. 31 f.: il.

Monografia (bacharelado) - Universidade de Brasília, Departamento de Administração - EaD, 2010.

Orientador: Profa. Mestre Marta Eliza de Oliveira, Departamento de Administração.

1. Gestão Ambiental. 2. Sustentabilidade 3. Banco do Brasil. I. Título. 


\section{LEANDRO MARINHO PINHEIRO DE SOUSA}

\section{GESTÃO AMBIENTAL NO BANCO DO BRASIL: uma visão de agência}

A Comissão Examinadora, abaixo identificada, aprova o Trabalho de Conclusão do Curso de Administração da Universidade de Brasília do (a) aluno (a)

\section{Leandro Marinho Pinheiro de Sousa}

\section{Mestre Marta Eliza de Oliveira}

Professora-Orientadora

Mestre Fabrícia Faleiros Pimenta Professora-Examinadora
Doutora Selma Lúcia M. Gonzalez Professora-Examinadora 
Dedico este trabalho primeiramente a Deus, pois sem Ele, nada seria possível e não estaríamos aqui reunidos.

À minha família; pelo esforço, dedicação e compreensão, em todos os momentos desta e de outras caminhadas.

Em especial, à minha esposa Michelle, por sua confiança, compreensão e comunhão. 


\section{AGRADECIMENTOS}

Aos meus colegas de equipe: Alisson, Giovanna, Leila e Cristiane; pelos momentos de aprendizagem constante e pela amizade solidificada, ao longo deste curso, que certamente se eternizará.

Aos professores e tutores pela contribuição, dentro de suas áreas, para o desenvolvimento desta monografia, e, principalmente, pela dedicação e empenho que demonstraram no decorrer de suas atividades para com o grupo. 
"Dolce è sentire, come nel mio cuore. Ora umilmente, sta nascendo amore. Dolce è capire che non son più solo, ma che son parte di una immensa vita. Che generosa, risplende intorno a me Dono di Lui del Suo immenso amore. Ci há dato il cielo e le chiare stelle. Fratello sole e sorella luna. La madre terra com frutti prati e fiori. II fuoco il vento, l'aria e l'acqua pura. Fonte di vita per le sue creature. Dono di Lui del Suo immenso amore. Dono di Lui del Suo immenso"

São Francisco de Assis (1181 - 1226) 


\section{RESUMO}

Esta pesquisa teve por objetivo identificar o nível de conhecimento e o envolvimento dos colaboradores do Banco Brasil, nos projetos de gestão ambiental que a empresa desenvolve, bem como a efetividade das políticas ambientais adotadas pela organização. $O$ trabalho considerou principalmente o fato de que o setor financeiro tem avançado bastante na aprendizagem de questões ambientais, buscando integrar o exercício de seu papel social as práticas de negócios e ressaltou a estratégia de negócio adotada pelo Banco do Brasil, no que tange à implementação de ações relacionadas à Agenda 21 e ao Programa de Ecoeficiência. Foram utilizados instrumentos característicos de uma pesquisa quantitativa, aplicada aos gerentes de vinte e cinco agências do Banco do Brasil localizadas no Distrito Federal. Os estudos evidenciaram que a visão de sustentabilidade ambiental dos funcionários entrevistados é contraditória, visto que, ao mesmo tempo em que declaram não ter conhecimento e nem participar das ações desenvolvidas pelo Banco do Brasil em termos de práticas ambientais, eles informam ser essas ações muitos importantes tanto para os clientes como para seus próprios ambientes de trabalho. Os resultados apontam que a grande maioria das ações adotadas são relacionadas ao monitoramento dos insumos utilizados nos processos de impressão ou utilização de papel e que as demais ações são direcionadas à racionalização no uso da água e à destinação dos resíduos sólidos. Para investigações posteriores, recomenda-se a ampliação da amostra, selecionando as demais agências de varejo do Banco do Brasil, inclusive de outros estados, bem como a incorporação de outros meios de comunicação.

Palavras-chave: Gestão ambiental. Sustentabilidade. Banco do Brasil. 


\section{LISTA DE FIGURAS e GRÁFICOS}

Figura 1. Desenvolvimento e Meio Ambiente: roda viva do consumo 21

Figura 2 o ponto doce da sustentabilidade.

Figura 30 ponto doce da sustentabilidade da GE. 26

Figura 4 O ponto doce da sustentabilidade da PepsiCo. 27

Figura 50 ponto doce da sustentabilidade da PepsiCo (processos ambientais)

Gráfico 1 Nível de conhecimento sobr4e os projetos de gestão ambiental desenvolvidos pelo BB .36

Gráfico 2 Grau de envolvimento com os projetos de gestão ambiental que o BB possui

Gráfico 3 Nível de importância dos projetos de gestão ambiental no trabalho diário

Gráfico 4 Importância da utilização de gestão ambiental na percepção dos clientes do BB 39

Gráfico 5 Ações de sustentabilidade desenvolvidas no ambiente de trabalho .40 


\section{LISTA DE SIGLAS E ABREVIAÇÕES}

BB

Banco do Brasil

FEBRABAN

Federação Brasileira dos Bancos

\section{OnGs}

Organizações Não Governamentais

\section{FGVces}

Centro de Estudos em Sustentabilidade da Escola de Administração de Empresas de São Paulo da Fundação Getúlio Vargas

\section{WBCSD}

World Business Council For Sustainable Development

\section{CLACDS}

Centro Latinoamericano Para La Competitividad Y El Desarrollo Sostenible 


\section{SUMÁRIO}

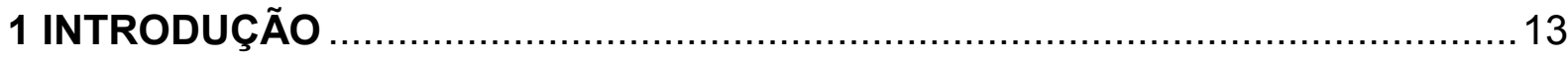

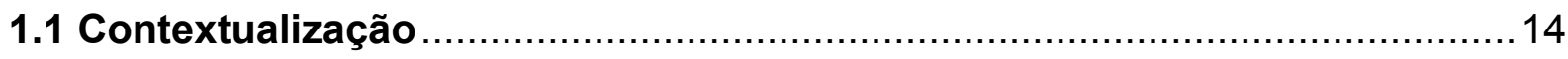

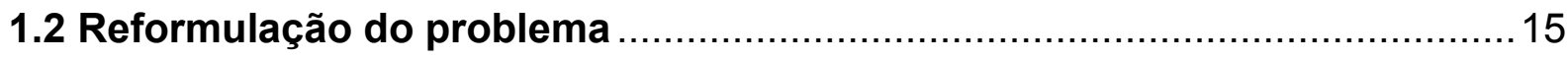

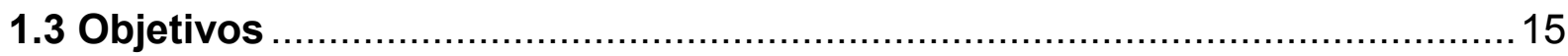

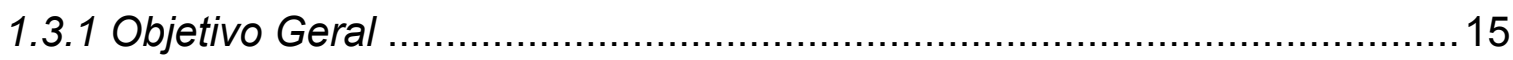

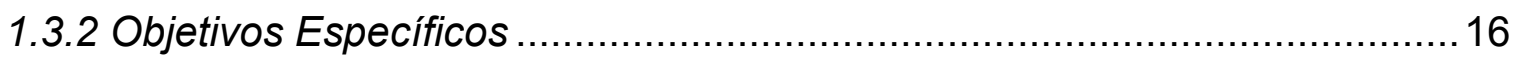

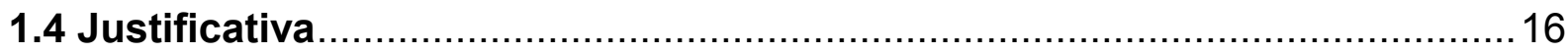

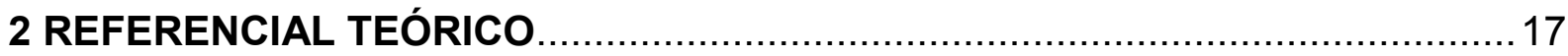

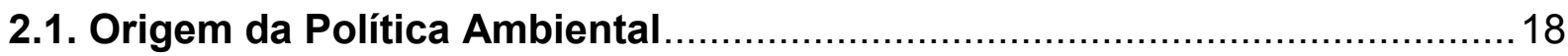

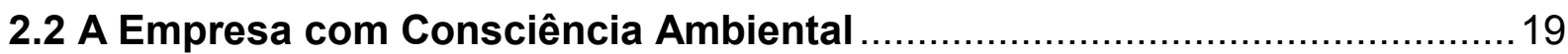

2.3 Impacto do Desenvolvimento Econômico sobre o Meio Ambiente ..............20

2.4. A Responsabilidade Social e Desenvolvimento Sustentável ....................22

2.4.1 Responsabilidade Social e Ambiental ................................................23

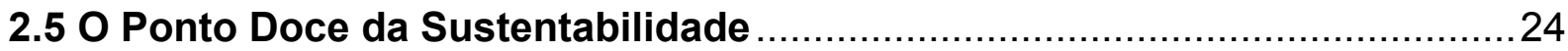

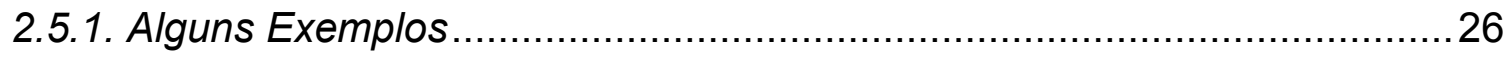

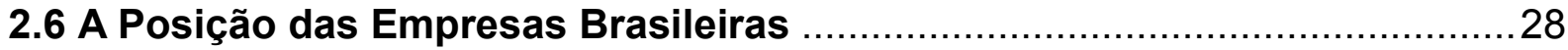

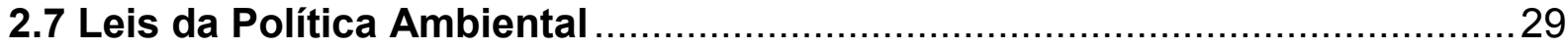

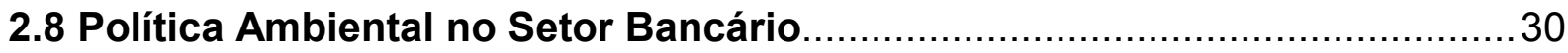

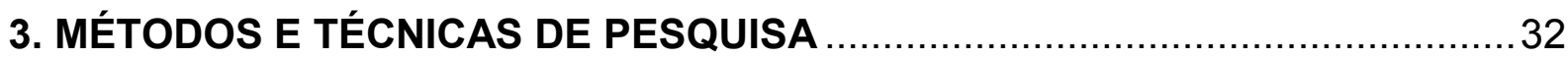

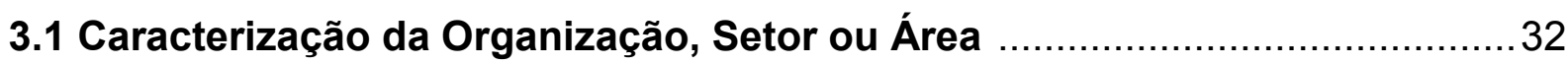

3.2 População e Amostra dos Participantes do Estudo....................................... 34

3.3 Caracterização dos Instrumentos de Pesquisa ……................................... 35 
3.4 Procedimentos de Coleta de Dados e de Análise de Dados .35

4 RESULTADOS E DISCUSSÃO 36

CONCLUSÕES E RECOMENDAÇÕES 41

REFERÊNCIAS 44

ANEXO 49 


\section{INTRODUÇÃO}

O Banco do Brasil (BB) decidiu, como parte da sua concepção, seguir os parâmetros norteadores da Agenda 21, amparado na estratégia de negócios para implementar o Programa de Ecoeficiência, um sistema de gestão ambiental que tem como objetivos reduzir a utilização de insumos, os custos operacionais e o impacto no ambiente, por meio do monitoramento e da avaliação sistemática e documentada do consumo e da destinação de resíduos oriundos do processo produtivo do BB.

O gerenciamento do Programa de Ecoeficiência e a divulgação de seus resultados são feitos por meio do acompanhamento de indicadores de consumo de insumos e de coleta seletiva dos resíduos gerados em cada unidade da empresa.

Esses monitoramentos do consumo, do descarte e da destinação de resíduos são passos fundamentais para uma certificação ambiental e para a adoção de um sistema de gestão ambiental empresarial que possibilita ao Banco do Brasil juntar-se às maiores empresas brasileiras no gerenciamento e redução de seus impactos ambientais. Porém, para que esse programa atinja os resultados esperados, é necessário que toda a empresa, em termos de seu corpo funcional, esteja alinhada com as ações a serem efetivadas.

Nesse contexto, vale ressaltar que o meio empresarial se depara, nos dias de hoje, com diversas questões que não se restringem meramente ao âmbito econômico. Além de mudanças nos próprios padrões de consumo, existe uma conjugação de fatores que indicam que as empresas não podem mais de preocupar simplesmente com o lucro (AZEVEDO, 2006).

Segundo Farias e Teixeira (2001), um dos maiores desafios dos estudiosos de administração é mostrar para as empresas a importância de mudar a concepção de Meio Ambiente e de moldar seus processos produtivos aos limites e condições que os meios natural e social impõem. A inserção da discussão ambiental nas empresas é resultado do crescimento da consciência ecológica que vem crescendo no ambiente dos negócios, motivado pela necessidade de cumprimento dos aspectos legais e pela adoção da filosofia de responsabilidade social pelas empresas. No entanto, esse nível de consciência pode variar entre diferentes 
sociedades e entre diferentes empresas, dependendo da atividade desenvolvida, dos seus objetivos, da sua cultura e do seu tamanho.

Seja por um processo de conscientização em assumir uma postura próativa, seja pela pressão do próprio mercado e das leis governamentais, já há no Brasil um segmento de empresas que considera importante assumir em suas diretrizes a preocupação com a temática do desenvolvimento sustentável.

Dentre as 500 maiores empresas brasileiras, cerca de $70 \%$ possui um sistema de gestão ambiental visando mapear o impacto ambiental, reduzir o consumo de insumos e aumentar a eficiência operacional (BANCO DO BRASIL, 2010). Estas empresas passaram a adotar estratégias que consideram a preservação ambiental, a transparência das ações empresariais, a responsabilidade com o crescimento econômico do País e o compromisso com o bem estar social.

As áreas de preocupação social incluem a poluição da água, do ar, visual e sonora, assim como a poluição por resíduo sólido e perigoso. Essas áreas são tão importantes para a empresa porque a legislação impõe obrigações e influi decisivamente na maneira como os negócios podem ser realizados. É preciso, a qualquer custo, otimizar o uso da energia, da água e da matéria-prima como forma de manutenção da biodiversidade do planeta, com a manutenção da qualidade dos mananciais, do solo e do ar, mediante conservação e uso parcimonioso das fontes de energia não renováveis (FARIAS e TEIXEIRA, 2002).

\subsection{Contextualização}

Hoje, um dos maiores desafios dos estudiosos de administração é mostrar para as empresas a importância de mudar a concepção de Meio Ambiente e de moldar seus processos produtivos aos limites e condições que os meios natural e social impõem. A inserção da discussão ambiental nas empresas é resultado do crescimento da consciência ecológica que vem crescendo no ambiente dos negócios, motivado pela necessidade de cumprimento dos aspectos legais e pela adoção da filosofia de responsabilidade social pelas empresas. No entanto, esse nível de consciência pode variar entre diferentes sociedades e entre diferentes 
empresas e até dentro de uma mesma organização, dependendo da atividade desenvolvida, dos seus objetivos, da sua cultura e do seu tamanho (FARIAS e TEIXEIRA, 2002).

\subsection{Formulação do problema}

Segundo a FEBRABAN (2004), o tema meio ambiente é de extrema relevância diante da complexidade do mundo dos negócios e do avançado estágio de degradação ambiental em todo o mundo. Está cada vez mais claro que não bastam certificações por normas ambientais, é preciso discutir em conjunto, soluções para problemas que afetam a sociedade contemporânea e ameaçam os direitos das futuras gerações.

O setor financeiro tem avançado bastante na aprendizagem de questões ambientais, buscando integrar o exercício de seu papel social às práticas de negócio.

A empresa relaciona-se com o meio ambiente causando impactos de diferentes tipos e intensidades. A responsabilidade empresarial voltada para o meio ambiente tem como foco a forma das empresas interagirem com o meio a qual estão inseridas, procurando minimizar os impactos negativos e ampliar os positivos, visando a manutenção e melhoria das condições ambientais e disseminando em outras empresas as práticas e conhecimentos adquiridos nesse sentido.

Diante desse contexto, foi proposto o seguinte questionamento: A visão de sustentabilidade é a mesma na estratégia da empresa e nas ações sustentáveis propriamente implementadas na prática?

\subsection{Objetivos}

\subsubsection{Objetivo Geral}

Avaliar a efetividade das políticas ambientais do BB em 25 agências de atendimento ao público vinculadas à Superintendência do Distrito Federal, regional Brasília. 


\subsubsection{Objetivos Específicos}

1 Caracterizar a visão de sustentabilidade ambiental dos funcionários do BB que trabalham em agências vinculadas à Superintendência do Distrito Federal, regional Brasília;

2 Verificar se as agências - objeto do estudo em questão -, possuem ações ambientalmente sustentáveis implementadas;

3 Relacionar as possíveis ações já implementadas;

4 Comparar se as possíveis ações implementadas estão alinhadas com as estratégias da empresa em termos de políticas ambientais.

\subsection{Justificativa}

A importância do tema está em demonstrar que a implementação de políticas públicas voltadas para a adequada gestão ambiental é vantajosa para as empresas e para a sociedade, considerando que podem gerar novas oportunidades de negócios e assegurar melhorias na qualidade de vida.

Considera-se que a importância do presente trabalho reside, principalmente, na identificação do nível de conhecimento e envolvimento dos colaboradores do Banco Brasil, nos projetos de gestão ambiental que a empresa desenvolve, bem como a efetividade das políticas ambientais adotadas pela organização.

Cabe registrar ainda que um dos fatores-chave da escolha do tema para o desenvolvimento do presente estudo foi a oportunidade de acesso às ações implementadas pelo Banco do Brasil e a possibilidade de efetivar comparações advindas das pesquisas, considerando que integro o quadro de funcionários da empresa. 


\section{REFERENCIAL TEÓRICO}

Tachiazawa (2002) afirma que com a consolidação da bioética global, no final da década de 1980, surge uma nova realidade socioambiental, redundando na mudança comportamental de postura do mundo empresarial. Fica para trás a velha forma de perceber 0 ambiente e de reação aos seus problemas. Gradativamente, começa-se a encarar a nova postura de responsabilidade ambiental como algo imprescindível à sobrevivência, em que a instituição empresarial passa a assumir um comprometimento sócio-político.

Neste contexto, muitos conceitos utilizados nas décadas passadas, de 1960 e 1970, foram reformulados, originando novas regulamentações e legislações emanadas do poder público. Com isso, nos dias atuais, muitas das decisões de âmbito empresarial precisam levar em conta os aspectos socioambientais.

Hoje, para a empresa desenvolver-se socioambientalmente tem que buscar e aplicar a ética corporativa e os valores institucionais. No novo milênio, é essa responsabilidade socioambiental que é o grande diferencial competitivo e a sustentabilidade das empresas que passaram a incorporar normas e procedimentos relacionados ao bem estar de toda a sociedade - atual e futura -, promovendo a qualidade antes e após suas produções. Trata-se de um novo olhar sobre a gestão (FÉLIX, IN: FÉLIX \& BORDA, 2009).

Não obstante ao fato de que a humanidade já esteja sinalizando sua busca por caminhos que levem a sustentabilidade, este processo ainda não apresenta indicadores prontos, estando esta caminhada longe de chegar ao seu final. Desde as conferências mundiais sobre o meio ambiente de Estocolmo- $72^{1} \mathrm{e}$

\footnotetext{
${ }^{1}$ A Conferência de Estocolmo - 1972 -, foi convocada pela Suécia em reação às chuvas ácidas que se precipitavam sobre o seu território e que, segundo se acreditava, eram originadas das instalações industriais localizadas na Alemanha e Inglaterra. A Conferência foi marcada por um clima pessimista que atribuía ao desenvolvimento, à criação de áreas poluídas e degradadas. Os resultados dessa análise do sistema da natureza em nível planetário foram publicados, em 1972, em um documento denominado "Os Limites do Crescimento", no qual defendia a necessidade de paralisação do crescimento econômico, como forma de impedir o progresso da poluição e da degradação ambiental. Esta proposição não obteve aprovação, pois implicaria em um processo de estagnação do status quo econômico internacional, mantendo os países paralisados em seus níveis de desenvolvimento (BURSZTIYN, 1993; FARIA, 1997; PEDRINI, 1997; BEZERRA \& BURSZTIYN, 2000; DIAS, 2000; ANTUNES, 2003).
} 
Rio- $92^{2}$, e mais recentemente, a Rio $+10^{3}$, várias possibilidades têm sido discutidas, com alguns avanços e também retrocessos, por conta de alguns países desenvolvidos, que resistem em não mudar seus conceitos, preferindo manter sistemas antigos (VIRTUOSO, 2004).

\subsection{Origem da Política Ambiental}

Segundo Costa (1999), a reação da sociedade contra o processo de degradação ambiental remonta há cerca de três décadas, época em que a maior parte das Organizações Não Governamentais (OnGs) existentes buscavam lidar com esta questão - ainda que de forma embrionária -, registrando-se, assim, uma história de longas e árduas lutas contra os agentes predadores do meio ambiente.

No entanto, apesar das concepções básicas do ambientalismo empresarial terem sido construídas a partir da Conferência de Estocolmo de 1972, seu marco histórico ocorreu somente em 1992, durante a preparação da Conferência das Nações Unidas para o Meio Ambiente e Desenvolvimento, a ECO 92. Tal conferência representou o auge do movimento a favor da sustentabilidade ambiental, tendo sido o ponto de partida das críticas mais fortes e consistentes com relação ao estado terminal de um modelo de desenvolvimento que cresceu em aberrantes contradições à dinâmica da natureza (SANTOS, 2003).

Nos primórdios do ambientalismo empresarial o principal obstáculo ao engajamento do empresariado na eco-eficiência residia na concepção dominante de

\footnotetext{
$2 \mathrm{Na}$ Rio-92, o próprio título oficial incorporou a preocupação dos países pobres com o desenvolvimento, motivo pelo qual a Conferência foi assim denominada de "Conferência das Nações Unidas sobre Meio Ambiente e Desenvolvimento" - CNUMAD. Sendo assim, a partir de 1992, a proteção do meio ambiente e desenvolvimento econômico passaram a ser vistos como duas faces de uma mesma moeda. Criou-se, a noção de Desenvolvimento Sustentável como fruto direto do trabalho da Comissão Brundtland, expresso no relatório "Nosso Futuro Comum" (CMMAD,1988).. No âmbito do soft law, a CNUMAD produziu a "Declaração do Rio" e a "Agenda 21". A chamada Agenda 21 é um conjunto de metas a serem atingidas pelas nações ao longo do presente século. Trata-se de medidas urgentes que devem ser empreendidas não só por governos, mas, principalmente, por cidadãos.

${ }^{3} \mathrm{Na}$ Conferência de Johanesburgo - Rio+10 -, em 2002, o Brasil desempenhou um importante papel ao colocar a questão da energia renovável, e ao propor metas mundiais para tal. Infelizmente, as propostas brasileiras não obtiveram o necessário consenso internacional, de forma a serem assimiladas pelo conjunto das Nações. A iniciativa tem a grande vantagem de aproximar mais os termos desenvolvimento e sustentabilidade, garantindo um equilíbrio entre eles, compondo um quadro mais harmônico.
} 
que a proteção ambiental e o lucro eram adversários naturais. Supunha-se que o mais adequado gerenciamento ambiental nas empresas, além de reduzir lucros, obrigaria estas a repassar os custos aos consumidores, via aumento de preços. Outrossim, o custo da tecnologia ambiental era alto em virtude de não estar nem tão disponível, nem tão aperfeiçoada como hoje. Entretanto, com o passar dos anos, tornou-se claro que as tecnologias ambientais possuíam um potencial inverso, ou seja, reduziam custos através de uma melhor racionalização dos processos produtivos, particularmente no uso de insumos e com relação ao desperdício (COSTA et al., 2007).

Dessa forma, este movimento representou a primeira mudança cultural de importância no pensamento empresarial quanto às questões ambientais. Desde então, tal modelo vem evoluindo, expandindo-se e adaptando-se cada vez mais a nossa realidade e demandas atuais.

O reconhecimento de que a proteção do meio ambiente e o desenvolvimento sustentável são responsabilidades coletivas e por isso devem se colocar entre as primeiras preocupações das atividades comerciais é tópico de relevo e reflexo instantâneo no mundo das instituições financeiras (SANTOS JUNIOR, 2006).

\subsection{A Empresa com Consciência Ambiental}

Os principais agentes do desenvolvimento econômico de um país são as empresas. A nova postura empresarial, sob os mais diversos avanços tecnológicos e a grande capacidade de geração de recursos, faz com que cada vez mais que as empresas precisem de ações cooperativas e integradas para promoverem uma Gestão Ambiental e a Responsabilidade Social (BOGER, 2005).

As empresas socioambientalmente responsáveis têm uma postura ética, a qual se torna o grande diferencial na escolha dos consumidores e colaboradores no mercado. É sob esta postura ética que se obtém, não só as vantagens competitivas, mas também o respeito da comunidade. 
praticam suas atividades, dessa forma, uma empresa que possua um modelo de Gestão Ambiental já está correlacionada à responsabilidade social. Tais eventos irão [...] interagir com as tomadas de decisões da empresa, tendo total importância na estratégia empresarial (GARNIER, 2009).

Assim, a Gestão Ambiental e a Responsabilidade Social são condicionadas pela pressão de regulamentações e pela busca de melhor reputação perante a sociedade (GARNIER, 2009). Hoje, pode-se dizer que toda a sociedade, aí incluídos o mercado empresarial, o cidadão comum, o consumidor final, tem consciência e reconhece a responsabilidade ambiental e social como valor permanente. E, sob esta consciência, passou-se a considerar como fator de avaliação e indicador de preferência para investidores e consumidores, a escolha de negociar com uma empresa ou não.

A partir da adoção de uma Gestão Ambiental e a consciência da Responsabilidade Social as empresas estão fortalecendo sua imagem de forma positiva perante as organizações nos mercados em que atuam - colaboradores, concorrentes e fornecedores.

\subsection{Impacto do Desenvolvimento Econômico sobre o Meio Ambiente}

Os efeitos negativos da ação do ser humano sobre o meio ambiente são graves. Corrigi-los nem sempre é possível, pois não há como retornar ao status quo (estado antes), mas é possível minimizar as consequências que advém do constante uso dos recursos naturais, sob uma mudança urgente de hábitos e atitudes.

O modelo de desenvolvimento hoje vivenciado pela sociedade estimula o consumo consciente (ou mesmo inconsciente) especialmente nas classes sociais de maior poder aquisitivo gerando imensas pressões sobre o meio ambiente (PINTO et al., 2008). "E esse consumismo insaciável de satisfação imediatista é a principal causa da degradação ambiental” (FÉLIX, 2008).

Para se alcançar a mudança desejada dos padrões atuais de consumo exige-se novas estratégias em várias frentes de atuação do gestor ambiental (FÉLIX, 
2008). Dessa forma, as empresas passaram a se preocupar mais com os valores éticos empresariais, tendo em vista que tal comportamento pode determinar a escolha dos consumidores/clientes.

A retirada desgovernada de insumos da natureza sem considerar a capacidade de reposição e o descarte de restos indesejados - processos marcados pelo desperdício - pressionam os ecossistemas, de maneira tal, que trazem à reflexão a responsabilidade social e ambiental que as mesmas devem ter como compensação ao acúmulo de riquezas e ao poder que exercem (FÉLIX, 2008).

A mudança de comportamento empresarial é necessária na contenção de tais desperdícios, para que esta possa estar envolvida em um processo empresarial consciente nas questões ambientais, ou melhor dizendo, aplicando de fato os conceitos que perfazem a gestão empresarial moderna. Há então, de se preocuparem não só com os ganhos com a divulgação, mas também com a manutenção da imagem de responsabilidade social exigida cada dia mais pelos consumidores.

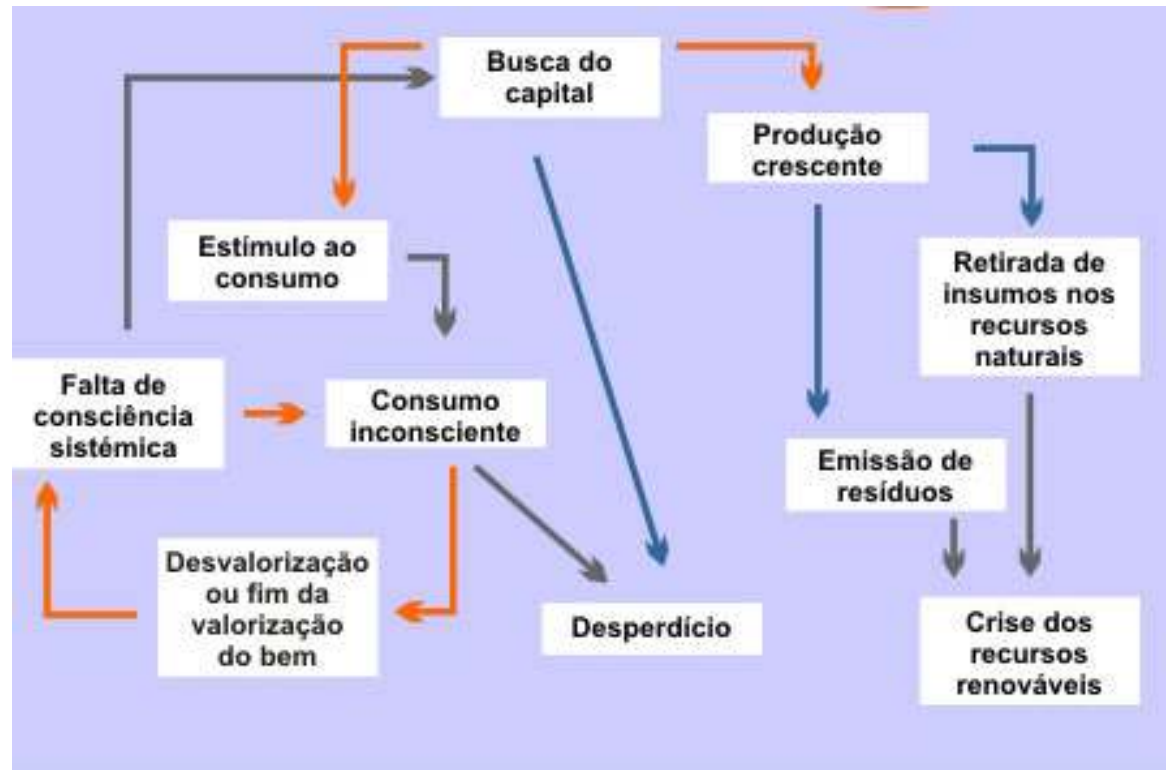

Figura 1. Desenvolvimento e Meio Ambiente: roda viva do consumo Fonte: Félix, 2008.

Por meio da figura 1, pode-se apontar os pontos que mais estimulam ou impactam fortemente as questões ambientais, sociais e econômicas de longo prazo. Daí parte-se para uma compreensão do que vem a ser a responsabilização social e também o que vem a ser o desenvolvimento sustentável. 


\subsection{A responsabilização social e o desenvolvimento sustentável}

O Instituto de pesquisa de mercado e opinião pública Market Analysis divulgou, em 2007, a Opinião dos Consumidores Brasileiros sobre a Imagem e Reputação das Grandes Empresas e o Mundo Corporativo. O Instituto realiza todo ano, o estudo Monitor de Responsabilidade Social no Brasil. O estudo envolve várias capitais - São Paulo, Rio de Janeiro, Belo Horizonte, Recife, Salvador, Porto Alegre, Curitiba, Goiânia e Brasília. A margem de erro é de aproximadamente 3,4\%. Os resultados demonstram que a comunicação e a ampliação de informação e conhecimento do consumidor exercem forte impacto sobre a imagem de marca da empresa. No entanto, dos eventos de divulgação dos produtos disponibilizados no mercado para consumo, advém uma conta ambiental elevada. Os impactos acontecem principalmente devido ao excesso de consumo de energia e da grande quantidade de lixo produzidos ao final de cada produção (AGÊNCIA PORTHIA, 2008).

A Fundação Getúlio Vargas com o objetivo de contribuir para minimização do impacto ambiental formulou o Catálogo de produtos e serviços sustentáveis para ajudar o consumidor consciente, bem como impulsionar empresas concorrentes para o desenvolvimento sustentável. O "Catálogo Sustentável" é uma ferramenta online que armazena informações sobre produtos e serviços avaliados e selecionados pela equipe de especialistas do Centro de Estudos em Sustentabilidade da Escola de Administração de Empresas de São Paulo da Fundação Getúlio Vargas (FGVces) a partir de critérios de sustentabilidade (EMPRESA RESPONSÁVEL, 2008).

Preocupados com essas questões, algumas empresas passaram a investir em alternativas para minimizar esses problemas, tais como, a adoção de áreas verdes como forma de compensar a poluição que causam. A estratégia desses grupos é financiar pequenos e médios proprietários de terra para que mantenham intactas suas áreas de floresta. O mote do programa não é o plantio de árvores, e sim evitar o desmatamento (MATA CILIAR). ${ }^{4}$ Legalmente, tais ações

\footnotetext{
${ }^{4}$ Um projeto no Paraná, capitaneado há quatro anos pela ONG ambientalista Sociedade de Pesquisa em Vida Selvagem e Educação Ambiental (SPVS), já permitiu a adoção, por parte de empresas e
} 
estão embasadas sob o Decreto $n^{\circ}$ 5.940, de 25.10.2006, que institui a separação dos resíduos recicláveis descartados pelos órgãos e entidades da administração pública federal direta e indireta, na fonte geradora, e a sua destinação às associações e cooperativas dos catadores de materiais recicláveis, e dá outras providências.

\subsubsection{Responsabilidade Social e Ambiental}

A Responsabilidade Social representa o compromisso contínuo da empresa com seu comportamento ético e com o desenvolvimento econômico, promovendo ao mesmo tempo a melhoria da qualidade de vida de sua força de trabalho e de suas famílias, da comunidade local e de toda a sociedade. Esse entendimento deve ser tão mais importante quanto à qualidade do produto ou do serviço, porque pode se tornar o fator diferencial para os termos de competitividade, etc. De acordo com Garnier (2009), "atualmente mais de $70 \%$ dos consumidores preferem marcas e produtos envolvidos em algum tipo de ação social".

A empresa que tem Responsabilidade Social significa que se torna parceira e co-responsável pelo desenvolvimento social, e passa a possuir a capacidade de ouvir os interesses das diferentes partes (acionistas, funcionários, prestadores de serviço, fornecedores, consumidores, comunidade, governo e meioambiente) e conseguir incorporá-los no planejamento de suas atividades (GARNIER, 2009).

Nos dias de hoje, não tem mais a opção de segredo absoluto nas decisões e ações empresariais, e por isso os princípios éticos elevados e a busca de qualidade nas relações são manifestações da responsabilidade social empresarial. "A transparência passou ser a alma do negócio: tornou-se um fator de legitimidade social e um importante atributo positivo para a imagem pública e reputação das empresas", promovendo e assegurando a sustentabilidade dos negócios, por

pessoas físicas, de uma área superior a 800 hectares, remanescentes de mata de araucária. A possibilidade de financiar a conservação dessas áreas chamou a atenção de empresas como Grupo Positivo, Rigesa Papel e Celulose e Sun Chemical. Agora, novos parceiros, como o HSBC Seguros e a Posigraf? unidade gráfica do Grupo Positivo -, aderiram ao programa. 
estarem sincronizadas com as novas dinâmicas que afetam a sociedade e o mundo empresarial (IBIDEM).

A sociedade de forma geral espera que as empresas cumpram um novo papel no processo de desenvolvimento: "sejam agentes de uma nova cultura, sejam atores de mudança social, sejam construtores de uma sociedade melhor" (IBIDEM)

A responsabilidade social e ambiental da empresa vai além da obrigação de respeitar as leis, pagar impostos e observar as condições adequadas de segurança e saúde para os trabalhadores. Suas ações são para se tornar melhor e participar da construção de uma sociedade mais justa; esta postura agrega valor à imagem da empresa.

A responsabilidade social e ambiental nos negócios é um conceito que se aplica a toda a cadeia produtiva, como demonstrada na figura 01. "Não somente o produto final deve ser avaliado por fatores ambientais ou sociais, mas o conceito é de interesse comum e, portanto, deve ser difundido ao longo de todo e qualquer processo produtivo" (IBIDEM).

\subsection{0 ponto doce da sustentabilidade}

Deve existir um ponto ideal para que os estudiosos do meio ambiente, os cientistas da sustentabilidade apontem como o ideal, o equilibrado. O ponto em que as empresas atuem em suas produções de produtos e serviços sem prejudicar o meio ambiente. Este ponto é o denominado por Savitz e Weber, de ponto doce da sustentabilidade.

Estamos convencidos de que num mundo mais globalizado, mais interconectado e mais competitivo, a maneira como se gerenciam as questões ambientais, sociais e de governança corporativa é parte da qualidade gerencial de que as empresas precisam para competir com sucesso. As empresas que apresentam melhor desempenho em relação a esses temas podem aumentar o valor para os acionistas, mediante, por exemplo, a boa gestão de riscos, a antecipação das iniciativas regulatórias ou o acesso a novos mercados, ao mesmo tempo em que contribuem para o desenvolvimento sustentável das sociedades em que operam. Além disso, essas questões podem exercer forte impacto sobre a reputação e marcas das empresas, fator cada vez mais importante para a avaliação do empreendimento (WORLD BANK, 2004). 
De acordo com Savitz e Weber (2007, p. 28) existe um mal entendido sobre a sustentabilidade, normalmente confundida com filantropia, que seria, por exemplo, a ação voluntariada de empregados de uma determinada empresa em programas de limpeza local, ou distribuição de alimentos para pobres.

A empresa sustentável conduz seus negócios, de modo a gerar naturalmente um fluxo de benefícios para tosos os seus stakeholders, inclusive empregados, clientes e parceiros de negócios, além da comunidade na qual opera, e também, os acionistas (IBIDEM). As empresas sustentáveis encontram áreas de interesse mútuo e desenvolvem maneiras de equiparar as expressões "fazer o bem" e "fazer bem-feito", evitando, assim, o conflito implícito entre comunidade e acionistas (SAVITZ e WEBER, 2007, p. 29). Para isso é necessário encontrar formas de encarar as operações rotineiras da empresa sob uma via expressa para o avanço na direção de ações que encontrem uma sustentabilidade constante.

Há um território compartilhado pelos interesses da empresa e pelos interesses do público. Essa área comum é o que Savitz e Weber (IBIDEM) denominam de "ponto doce da sustentabilidade": o lugar em que a busca do lucro se mistura de maneira inseparável com a busca do bem comum (ver figura 2).

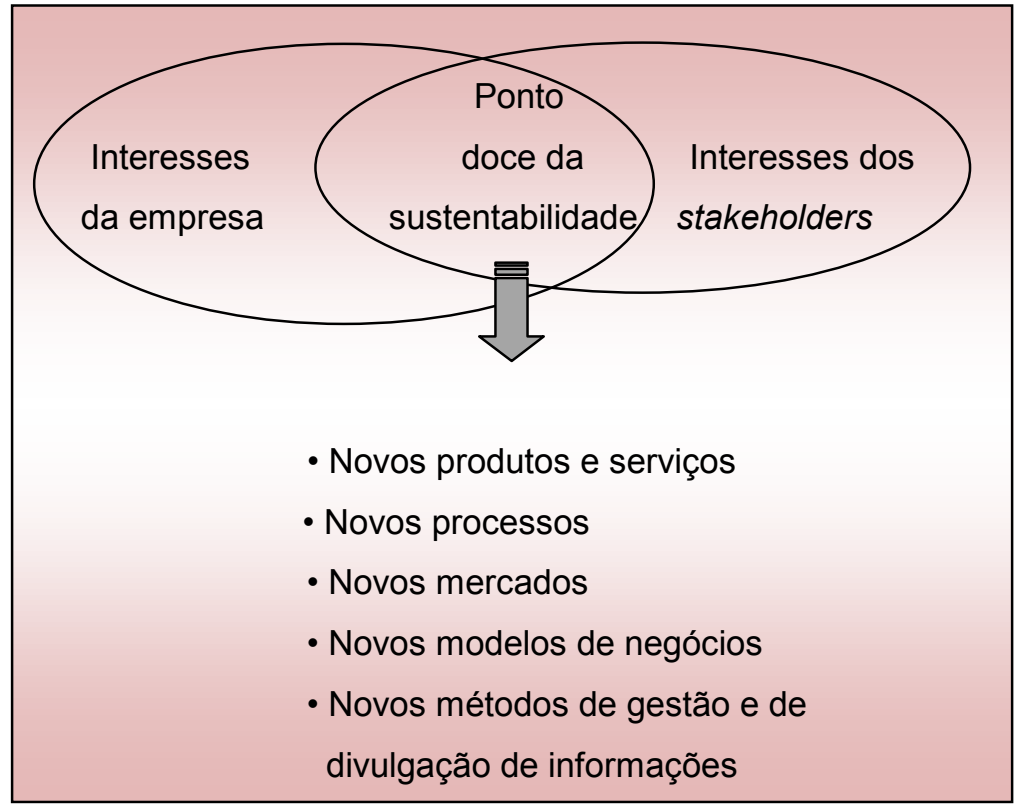

Figura 2. O Ponto doce da sustentabilidade

Fonte: Savitz e Weber, 2007. p. 30. 
Ponto doce é a situação ou lugar em que certa combinação de fatores proporciona as melhores condições para a realização de um objetivo. Equivale, em geral, ao centro de percussão, calculável mediante fórmulas matemáticas, embora observações práticas recentes sugiram que nem sempre ocorra tal correspondência (SAVITZ e WEBER, 2007, p. 29).

\subsubsection{Alguns Exemplos}

As empresas mais bem gerenciadas em todo o mundo estão tentando localizar e atuar nessas regiões de interesses mútuos, desenvolvendo novas maneiras de fazer negócios, a fim de localizar essas áreas e nelas se estabelecer. Tem-se o exemplo da GE que em 2005 anunciou um programa chamado Ecomagination. Trata-se de ótimo exemplo de como descobrir e trabalhar no ponto doce. É ação que vai além do simples cumprimento das leis, para beneficiar tanto a sociedade, quanto a solidez duradoura do empreendimento. O principal objetivo da Ecomagination, explicam Savitz e Weber (2007, p. 30), é desenvolver tecnologias limpas para ajudar os clientes da GE a reduzir seus impactos ambientais, principalmente emissões de carbono (ver figura 3).

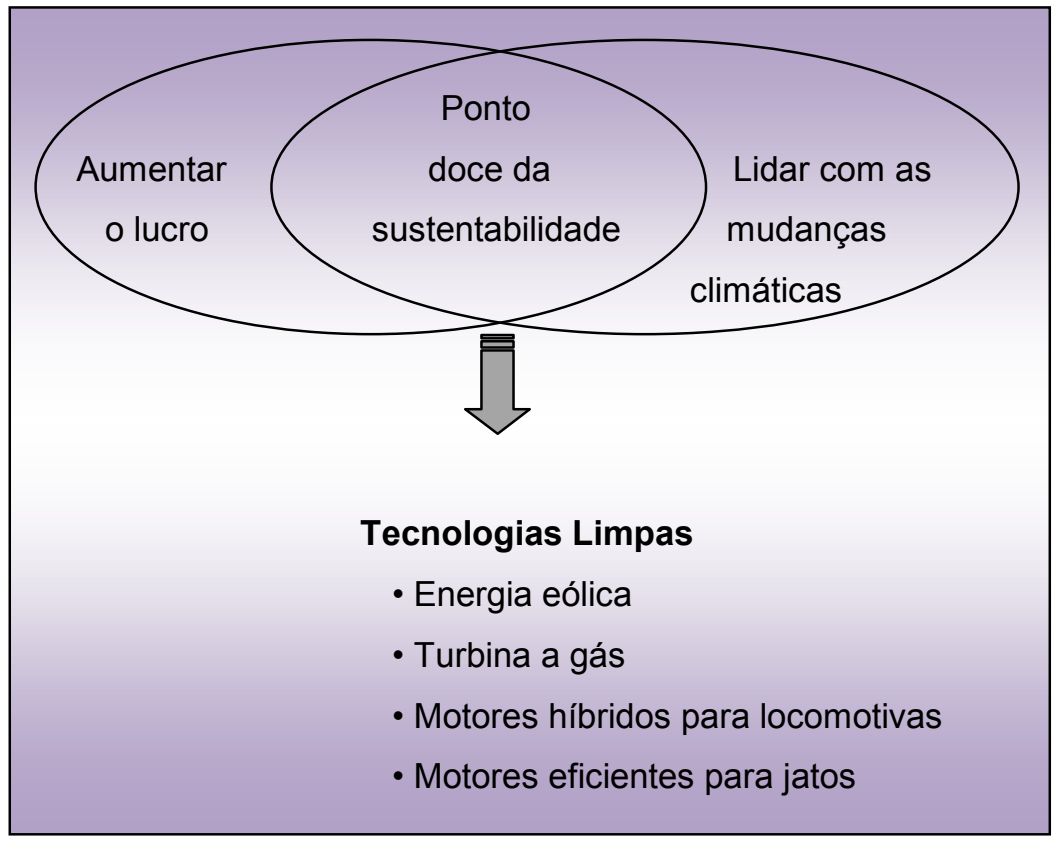

Figura 3. O Ponto doce da sustentabilidade da GE

Fonte: Savitz e Weber, 2007. p. 32. 
A Ecomagination da GE confirma que as grandes empresas precisam inserir as questões sociais em suas estratégias, de modo a refletir sua importância para os negócios (SAVITZ e WEBER, 2007, p. 31).

A sobreposição entre conquistar fatias de mercado cada vez maiores e promover estilos de vida mais saudáveis é um ponto doce para a PepsiCo (ver Figura 4). A idéia de produtos não-prejudiciais ou até benéficos à saúde é um desafio para uma empresa famosa por suas bebidas e biscoitos salgados. A empresa transformou o ponto doce dos produtos saudáveis no segmento mais dinâmico de seu portfólio de produtos, cujas receitas em 2005 cresceram a taxas mais de duas vezes e meia superiores às dos produtos tradicionais. Assim, a responsabilidade social contribuiu para que o lucro por ação da PepsiCo aumentasse 13\% em 2004 e para que o valor de mercado da empresa ultrapassasse o da Coca-Cola pela primeira vez na história (SAVITZ e WEBER, 2007, p. 31).

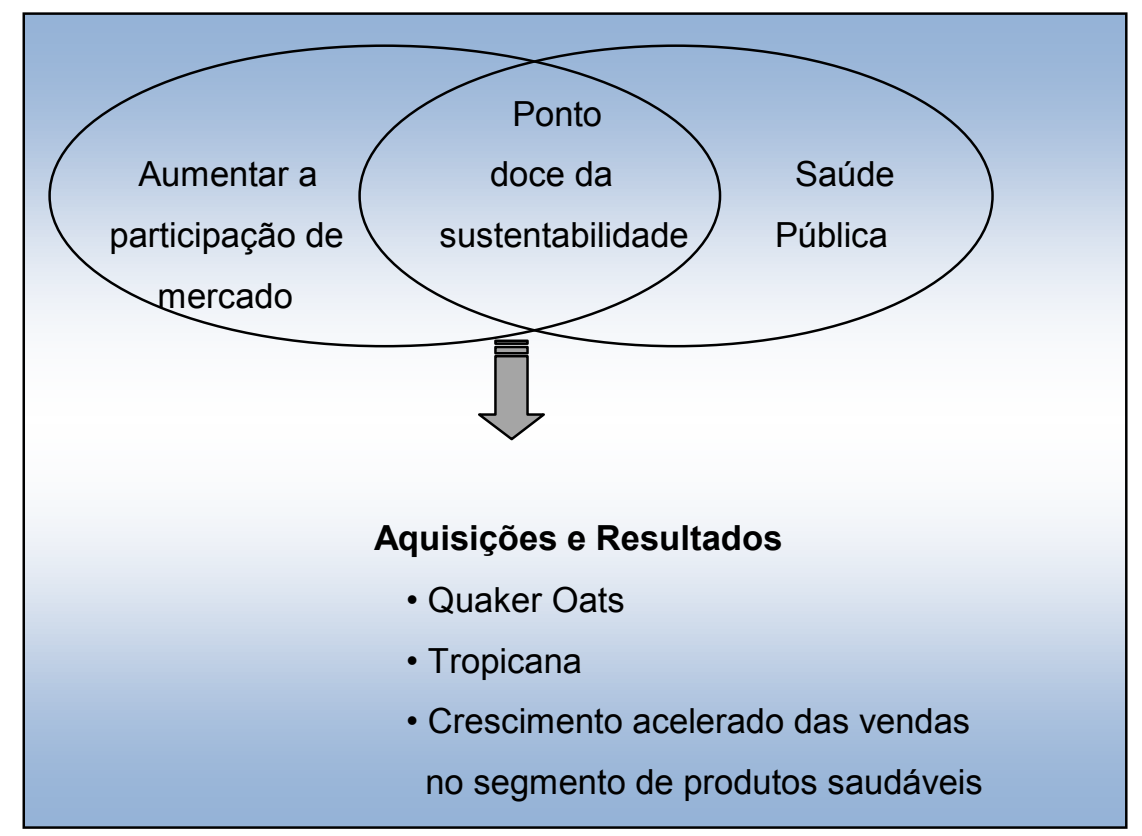

Figura 4. O Ponto doce da sustentabilidade da PepsiCo

Fonte: Savitz e Weber, 2007. p. 33.

A PepsiCo está buscando outros pontos doces.Seu objetivo de redução de custos se sobrepõe com uma série de melhorias ambientais para reduzir o consumo de energia, a geração de efluentes e os resíduos de embalagem (ver figura $5)$. 


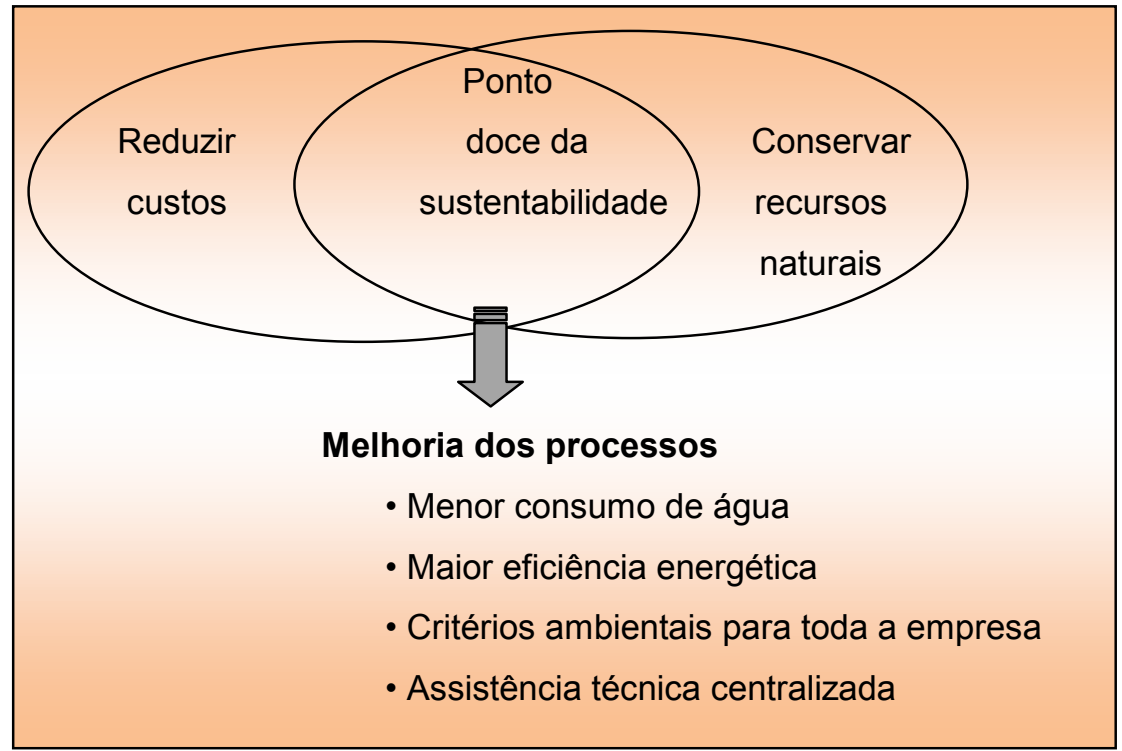

Figura 5. O ponto doce da sustentabilidade da PepsiCo (processos ambientais)

Fonte: Savitz e Weber, 2007. p. 34.

O objetivo da PepsiCo é o de reduzir os riscos, em longo prazo, com questões referentes a abastecimento e qualidade da água, de grande importância para as comunidades em que situam suas fábricas. Essas ações responsáveis beneficiam a todos no ambiente interno e externo da empresa, ao mesmo tempo em que aumentam o valor para os acionistas e criam condições mais saudáveis e sustentáveis para as operações da empresa.

Enfim, importa compreender que o conceito de ponto doce corresponde ao significado literal de "sustentabilidade", garantindo a viabilidade da empresa em longo prazo, com base em princípios de gestão que fortalecerão suas raízes de empresa no meio ambiente, no tecido social e na economia. Sustentabilidade passa a significar gestão esclarecida e disciplinada - que é o fator mais importante que os investidores levam em conta e devem ter em vista nas suas decisões de compra de ações (SAVITZ e WEBER, 2007, p. 38).

\subsection{A Posição das Empresas Brasileiras}

No Brasil, o movimento de valorização da responsabilidade social empresarial ganhou forte impulso na década de 90. Primeiramente por meio da 
Agenda 21, o encontro de vários Estados e várias empresas, além das ações de entidades não governamentais, institutos de pesquisa e empresas sensibilizadas para a questão. A exigência no mercado, na troca de serviços, de certificados de padrão de qualidade e de adequação ambiental, como às normas ISO, também se tornou símbolo dos avanços obtidos em alguns aspectos importantes da responsabilidade sócio-ambiental (GARNIER, 2009).

O setor privado vem demonstrando grandes conquistas no sentido da responsabilidade sócio-ambiental. O índice Dow Jones Mundial de Sustentabilidade (DJSI) (RODRIGUES, s/d) ${ }^{5}$, embasado em questões de sustentabilidade, como governança corporativa, gestão da marca e de risco, até as mais específicas para a indústria de petróleo e gás, como mudança climática, padrões para fornecedores e gestão de projetos sociais; as empresas desejam e buscam obter o índice Dow Jones para se manterem no mercado competitivo e globalizado. ${ }^{6}$

\subsection{Leis de política ambiental}

A Lei de Política Nacional de Meio Ambiente em seus artigos $3^{\circ}, 12^{\circ}$. e $14^{\circ}$, traz dispositivos que, aplicados às instituições financeiras, em amplo sentido, eleva o financiamento, o crédito, ao nível de instrumento de controle ambiental.

O artigo $3^{\circ}$ prevê equivalência na reparação do dano para os poluidores, considerado estes os responsáveis diretos ou indiretos pela atividade causadora de degradação ambiental. Já o artigo $12^{\circ}$ enumera que as entidades ou

\footnotetext{
${ }^{5} \mathrm{O}$ Índice Mundial de Sustentabilidade Dow Jones é o primeiro índice a acompanhar o desempenho das empresas líderes mundiais em compromisso com a sustentabilidade. As empresas são selecionadas para o índice após uma minuciosa avaliação segundo critérios econômicos, ambientais e sociais. Para as instituições privadas, fazer parte deste grupo seleto, hoje, significa o reconhecimento de que suas atividades são desenvolvidas conforme os princípios do desenvolvimento sustentável, sendo capaz de criar valor para os acionistas. RODRIGUES, s/d.

${ }^{6}$ As empresas que no Brasil integram Índice Dow Jones Mundial de Sustentabilidade (DJSI): Aracruz Celulose, Banco Bradesco, Banco Itaú, Companhia Energética de Minas Gerais (CEMIG). No setor de petróleo e gás estão incluídas: Petrobrás, BG Group, BP PLC, EnCana, Nexen Inc, Repsol YPF, Royal Dutch Shell, Shell Canada Ltd., Statoil, Suncor Energy Inc., Total S.A. O levantamento da Market Analysis de 2007 aponta as dez melhores corporações em Responsabilidade Social atuantes no Brasil. Entre as melhores avaliadas estão Petrobras, Nestlé, Coca-Cola, Rede Globo, Unilever, Natura, Vale do Rio Doce, AmBev, Bom Preço e Azaléia.
} 
órgãos de financiamento e incentivo governamental condicionarão a aprovação de projetos habilitados a esses benefícios ao licenciamento, na forma da lei, e ao cumprimentos das normas, dos critérios e dos padrões expedidos pelo Conselho Nacional do Meio Ambiente, concluindo com o artigo $14^{\circ}$ que "sem obstar a aplicação de penalidades previstas neste artigo, é o poluidor obrigado, independente de existência de culpa, a indenizar ou repara os danos causados no meio ambiente" (SANTOS JUNIOR, 2006).

\subsection{Política Ambiental no setor bancário}

A Lei no. 6.938/81, que institui a Política Nacional de Meio Ambiente, também prevê que os financiamentos, principalmente aqueles de incentivo governamental, deverão incorporar o componente ambiental quando de seu deferimento, a partir da realização de estudos de impacto ambiental prévios à análise dos projetos e ao deferimento do crédito, tal como já vem ocorrendo no âmbito do Banco Mundial (SANTOS JUNIOR, 2006).

Em resposta a todo esse desafio, as empresas passaram a investir em qualidade, primeiramente centrando a atenção nos produtos, depois evoluindo para a abordagem dos processos e culminando no tratamento abrangente das relações entre a atividade empresarial, os empregados, os fornecedores, os consumidores, a sociedade e o meio ambiente (SANTOS, 2003).

Nesse contexto, os bancos brasileiros de varejo têm assumido posições pró-ativas na administração dos impactos ambientais de suas atividades. Sob a perspectiva do gerenciamento dos riscos de crédito, operacional, legal e de imagem, tornou-se imprescindível a aplicação adequada dos seus recursos destinados ao fomento das atividades produtivas, especialmente as potencialmente poluidoras. Ainda que a indústria financeira atinja em menor intensidade o meio ambiente, se comparada às indústrias de transformação e extrativista, sua intermediação na exploração e direcionamento da poupança interna pode incentivar ou desestimular o desenvolvimento regional sustentável (SANTOS e FINAZZI, 2008). 
Os bancos têm por função intermediar os recursos dos agentes poupadores com as necessidades de financiamento dos agentes deficitários. Por esse motivo, possuem responsabilidades pelo desenvolvimento sustentável e o meio ambiente (WBCSD, 2001).

A assinatura da Declaração dos Bancos para o Meio Ambiente e Desenvolvimento Sustentável, ocorrida em Nova lorque, em maio de 1992, por mais de 30 Bancos comerciais de 23 países diferentes, comprometendo suas operações financeiras com princípios comuns pela proteção do meio ambiente, deixa antever a cena descrita acima como uma real possibilidade (INSTITUTO ETHOS, 2003).

Os bancos desenvolveram estratégias de relacionamento com as diversas partes interessadas em sua atuação, a saber: comunidade, clientes, Poder Público, acionistas, investidores, empregados, sindicatos e ONGs. A transparência na relação com os stakeholders foi institucionalizada pelos programas de responsabilidade socioambiental, os quais, segundo Ashley (2005), referem-se ao "compromisso que a organização deve ter para com a sociedade, expresso por meio de atos e atitudes que a afetam positivamente".

Ao mesmo tempo, os indicadores de desempenhos financeiros tornaram-se incipientes para avaliar a complexidade de suas interações. Assim, emergiu o indicador de eficiência ecológica, que diz respeito ao estabelecimento de vantagem competitiva sustentada, baseada em maior produtividade dos recursos materiais e energia, com menor impacto ambiental, cujo fim é o desenvolvimento do homem e da sociedade (CLACDS, 2008). 


\section{MÉTODOS E TÉCNICAS DE PESQUISA}

Foram utilizados instrumentos característicos da uma pesquisa quantitativa, por meio da aplicação de questionário virtual aos funcionários do nível de gerência superior, de vinte e cinco (25) agências do Banco do Brasil, no Distrito Federal. O objetivo foi identificar o nível de conhecimento, o envolvimento dos colaboradores da empresa nos projetos de Gestão Ambiental que a empresa desenvolve, bem como a efetividade das políticas ambientais do BB nas agências em questão.

As informações obtidas permitiram estabelecer um parâmetro da aplicabilidade da política que a empresa adota para a Gestão Ambiental e Responsabilidade Social.

\subsection{Caracterização da organização, setor ou área}

O Banco do Brasil informa ser a maior instituição financeira da América Latina em termos de ativos segundo ranking da consultoria Economática, com base em informações obtidas com dados de dezembro de 2009. O Banco do Brasil é um banco múltiplo com sede em Brasília, Distrito Federal, tem presença significativa em todos os estados brasileiros, além de desenvolver atividades em importantes centros financeiros mundiais.

Seu foco é realizar negócios orientados à geração de resultados sustentáveis e desempenho compatível com suas lideranças de mercado. Como agente de políticas públicas, o Banco do Brasil apóia o agronegócio, as micro e pequenas empresas e o comércio exterior brasileiros, tanto por meio da execução de programas federais como pelo desenvolvimento de soluções que buscam simplificar as operações e serviços que atendem esses segmentos da economia.

Com mais de 200 anos de história, sua principal força está no segmento de varejo bancário. De maneira geral, seus negócios podem ser agrupados em sete grandes segmentos: (i) Bancário; (ii) de Investimentos; (iii) de 
Gestão de Recursos; (iv) de Seguros e Saúde; (v) de Previdência e Capitalização; (vi) de Meios de Pagamento; e (vii) Outros Segmentos. As principais atividades de cada segmento estão dispostas a seguir:

(i) Segmento Bancário: prestação de serviço bancário em todos os segmentos de atuação;

(ii) Segmento de Investimentos: participação em sociedades seguradoras, de capitalização e entidades abertas de previdência complementar;

(iii) Segmento de Gestão de Recursos: administração e gestão de recursos de terceiros, organização e administração de fundos e clubes de investimento e administração de carteiras e custódia de títulos e valores mobiliários;

(iv)Segmento de Seguros e Saúde: atuação no ramo de seguros elementares, saúde e vida nas modalidades de riscos pessoais, patrimoniais, de transportes, rurais e de garantias, serviços médicos e seguro odontológico;

(v) Segmento de Previdência e Capitalização: comercialização de produtos de previdência complementar, instituindo e executando planos de benefícios de caráter previdenciário, e títulos de capitalização;

(vi)Segmento de Meios de Pagamento: prestação de serviços relacionados a estabelecimentos comerciais por meio de convênios de meios de pagamento de benefícios, incluindo benefícios de alimentação, refeição, transporte e combustível; e

(vii) Outros Segmentos: além da atuação nos segmentos citados anteriormente, o Banco do Brasil atua em outros ramos de atividades onde se destacam:

- Aquisição e/ou gestão de créditos oriundos de operações de bancos, sociedades de crédito imobiliário, de arrendamento mercantil;

- Participações no setor elétrico;

- Arrendamento mercantil de bens móveis ou imóveis; 
- Administração de grupos de consórcio; e,

- Comercialização, instalação, manutenção de computadores e periféricos.

Em 31.3.2010, o Banco do Brasil registrou mais de 53,5 milhões de clientes (52,2 milhões em 31.12.2009) atendidos a partir de uma rede de 18,0 mil pontos de atendimento $(17,9 \mathrm{mil}$ em 31.12.2009) e 45,8 mil terminais de autoatendimento (TAA) $(45,4$ mil em 31.12.2009) próprios distribuídos em 3,5 mil municípios brasileiros, com envolvimento de 103,9 mil funcionários (104,0 mil em 31.12.2009).

A Superintendência do Banco do Brasil no Distrito Federal engloba o quantitativo de dois mil e trezentos (2.300) funcionários. É uma das mais rentáveis e importantes para a empresa. Possui cerca de cento e nove (109) agências de atendimento ao público, sendo cinqüenta e três (53) vinculadas à Regional Brasília, que abrange também as sete (7) agências Estilo, destinadas a atender o público de alta renda.

\subsection{População e amostra ou participantes do estudo}

Os participantes do estudo foram os funcionários do nível de gerência superior de vinte e cinco (25) agências do Banco do Brasil, pertencentes à região do Distrito Federal, o que representa um percentual de $50 \%$ das agências vinculadas à Regional Brasília, conforme total apontado anteriormente.

\subsection{Caracterização dos instrumentos de pesquisa}

O questionário aplicado foi dotado de cinco (5) questões fechadas, com respostas diretas ao tema elaborado. Da primeira questão para a última, há uma evolução gradual da busca por conhecimento de como o tema "Gestão Ambiental" tem absorvido cada colaborador dentro da Empresa Banco do Brasil, além de 
investigar se há não só o envolvimento desse colaborador, como se a empresa tem alcançado de forma efetiva seus objetivos com os projetos desenvolvidos.

As respostas permitiram a construção de uma validação científica para a conclusão deste trabalho, sob forma estatística. Os resultados aqui obtidos, permitiram também, fazer um conexão clara e direta com os objetivos propostos.

Desta forma, foi evidenciado que as variáveis ou os construtos de pesquisa - caracterizar a visão de sustentabilidade ambiental dos funcionários do BB que trabalham em agências vinculadas à Superintendência do Distrito Federal, regional Brasília; Verificar se as agências, possuem ações ambientalmente sustentáveis implementadas; relacionar as possíveis ações já implementadas; comparar se as possíveis ações implementadas estão alinhadas com as estratégias da empresa em termos de políticas ambientais -, permitiram que a pesquisa fosse operacionalizada.

\subsection{Procedimentos de coleta e de análise de dados}

As resposta dada pelos entrevistados foi coletada através do site www.zoomerang.com de forma anônima visto que ao entrevistado bastava acessar o link da pesquisa (http://www.zoomerang.com/Survey/WEB22B8UVVRG2B), enviada via email, e responder o questionário (ANEXO A).

Os dados coletados foram classificados em categorias de um ordenamento pré-estabelecido e analisados em termos percentuais ou de freqüência de aparição. 


\section{RESULTADOS E DISCUSSÃO}

Para a questão $\mathrm{n}^{\circ} 1$ - Qual é o nível de conhecimento sobre os projetos de gestão ambiental desenvolvidos pelo BB? - obteve-se $4 \%$ de respostas para "nenhum conhecimento sobre o tema"; $16 \%$ de respostas para "grande conhecimento sobre o tema"; e, $80 \%$ para resposta "pouco conhecimento sobre o tema".

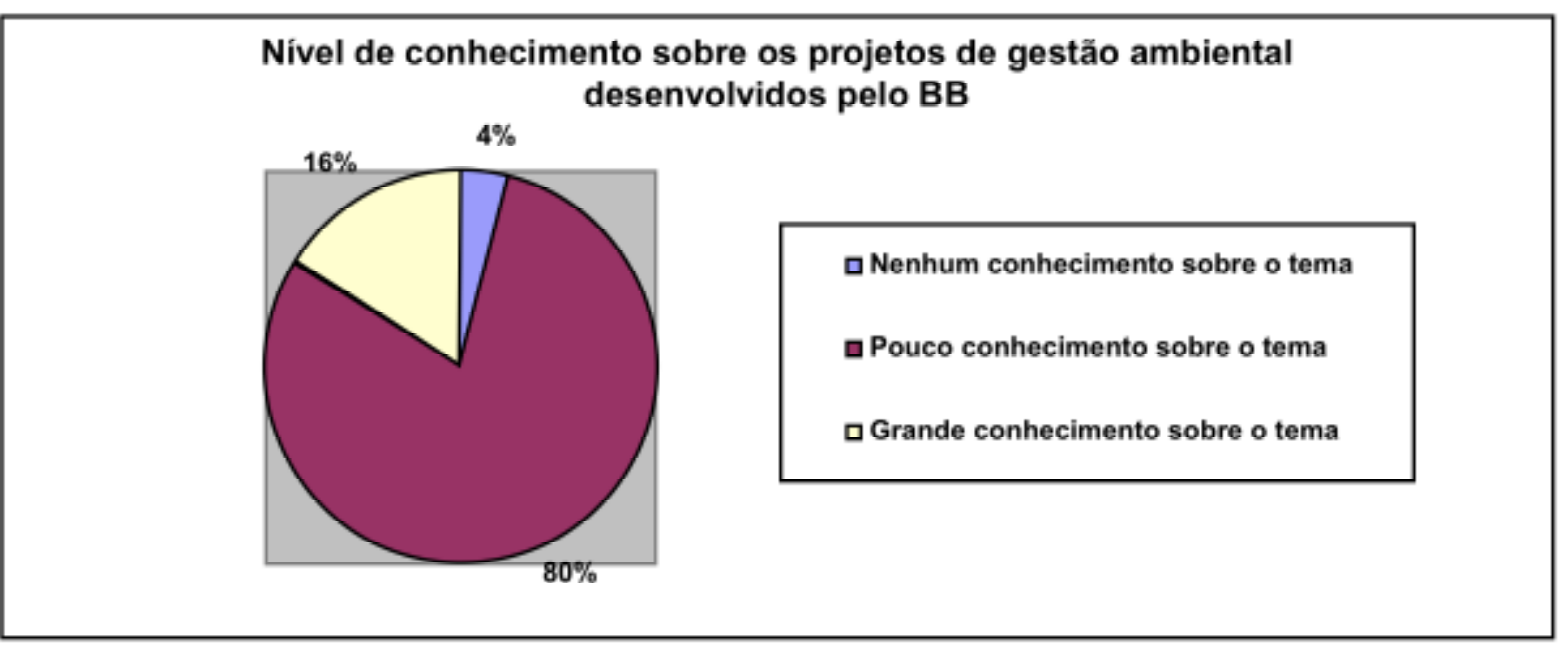

Gráfico 1 Nível de conhecimento sobre os projetos de gestão ambiental desenvolvidos pelo BB

O resultado das respostas aqui coletadas, demonstram que as informações não condizem com a importância com que o assunto é tratado dentro da empresa. No Banco do Brasil, a Diretoria Relações com Funcionários e Responsabilidade Socioambiental está vinculada à Vice-Presidência de Gestão de Pessoas e Responsabilidade Socioambiental. Além da unidade, há um grupo permanente de discussão, denominado Grupo RSA, cujo objetivo é "mapear e integrar as ações sociais e ambientais desenvolvidas em âmbito empresarial, buscando a ampliação dos benefícios produzidos" (BANCO DO BRASIL, 2007).

Inexistem receitas prontas e unívocas que convertam conhecimentos sobre a importância do tema "meio ambiente" em informações a serem utilizadas na empresa para seus funcionários. O conhecimento é multidimensional, envolve disciplinas e pontos de vistas diversificados. Por essa razão, evidencia-se aqui, a necessidade de uso de material auxiliar para o empreendimento dos projetos desenvolvidos pelo grupo RSA no BB. Ou seja, para tal, é necessário arrolar alguns recursos cognitivos - saberes, critérios, técnicas, atitudes e princípios - que, ao 
serem mobilizados, podem ajudar o desenvolvimento de cursos, projetos ou materiais para o desenvolvimento e conhecimento do tema ambiental. Esses recursos são úteis tanto para a comunicação sobre o tema ambiental. Outro aspecto importante é o tratamento profundo das informações. Profundidade não que dizer texto difícil e rebuscado para dar uma aparente idéia de complexidade - ao contrário, os materiais disponibilizados para todos os funcionários ou colaboradores, devem ser simples. A criação de materiais investigados com minúcia sobre as verdadeiras causas da degradação ambiental depende mais da compreensão de conceitos, conteúdos e problemáticas ambientais, em seus aspectos sociais e econômicos, do que de truques.

Para a questão $\mathrm{n}^{\circ} 2$ - Qual é o seu grau de envolvimento com os projetos de gestão ambiental que o BB possui? -, obteve-se o seguinte resultado: $8 \%$ para a resposta "grande envolvimento com os temas"; $40 \%$ para a resposta "nenhum envolvimento com os temas"; e, 52\% para a resposta "pouco envolvimento com os temas".

Grau de envolvimento com os projetos de gestão ambiental que o BB possul

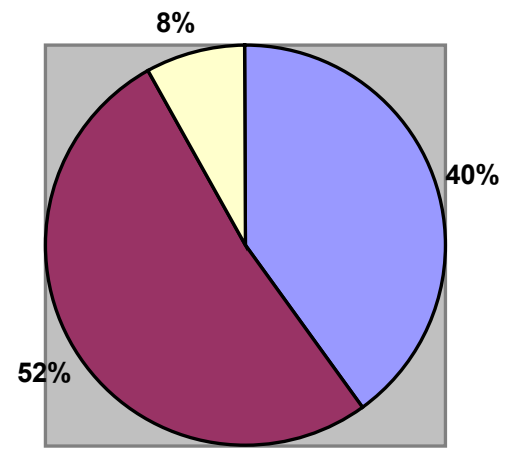

$\square$ Nenhum envolvimento com os temas

$\square$ Pouco envolvimento com os temas

口Grande envolvimento com os temas

Gráfico 2 Grau de envolvimento com os projetos de gestão ambiental que o BB possui

Esses resultados também não condizem com a informação apurada por Santos e Finazzi (2008). Segundo eles, o BB é um dos únicos bancos que manifesta comprometimento com o meio ambiente, explicitado-a em documento estratégico - Visão, Missão, Políticas e Valores. No BB, o meio ambiente é mencionado inclusive na declaração de Valores da empresa: "Responsabilidade socioambiental e respeito à diversidade". 
É necessário implementar ações que busquem avançar na construção e comunicação de mensagens claras sobre os projetos de gestão ambiental desenvolvidos dentro do $\mathrm{BB}$, de forma que se amplie o envolvimento de cada colaborador; necessário ainda então, que revisem as formas de comunicação intrabanco para os programas de gestão ambiental para orientá-los e envolvê-los nesse desenvolvimento; e que por fim, respaldem e impulsionem a nível regional, a cooperação para o desejado desenvolvimento sustentável dentro do Banco do Brasil, na promoção da empresa para a toda a Nação brasileira. Este seria o ponto de partida, e sendo assim, evidencia-se a necessidade de elaborar documentos teórico-práticos, que, a partir do contexto regional possam ser realizadas propostas, projetos e programas e/ou planos, que se desenvolvam no campo da educação ambiental dos funcionários do Banco do Brasil para o desenvolvimento real e de fato sustentável.

Para a questão $\mathrm{n}^{\circ} 3$ - Na sua opinião, referente aos projetos de gestão ambiental desenvolvidos pelo BB, qual o nível da importância destes no seu trabalho diário? -Para a resposta "nenhuma importância no meu trabalho diário", obteve-se $4 \%$ de respostas; para a resposta "pouca importância no meu trabalho diário", obteve-se $40 \%$ das respostas; e, para a resposta "grande importância no meu trabalho diário", obteve-se $56 \%$ das respostas (Gráfico 3 ).

Nível de importância dos projetos de gestão ambiental no trabalho diário

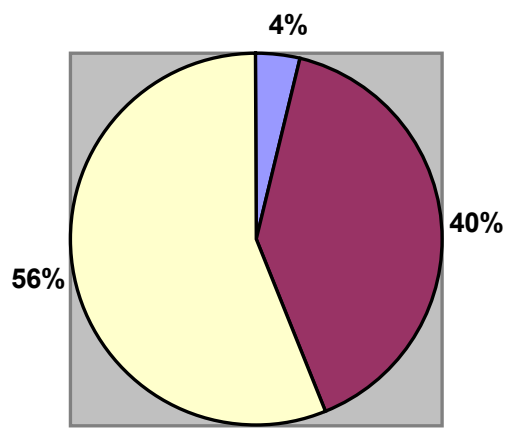

$\square$ Nenhuma importância no meu trabalho diário

口Pouca importância no meu trabalho diário

口Grande importância no meu trabalho diário

Gráfico 3 Nível de importância dos projetos de gestão ambiental no trabalho diario 
Constata-se, assim, que os funcionários, em sua grande maioria, não possuem o conhecimento da política ambiental da empresa e de seus projetos. Consideram importantes, ainda que possuam um envolvimento em suas ações efetivas compatível com o nível de conhecimento, no entanto, não absorvem a importância necessária.

Segundo Kraemer (2004), para que uma empresa passe a realmente trabalhar com gestão ambiental deve, inevitavelmente, passar por uma mudança em sua cultura empresarial; por uma revisão de seus paradigmas. Ou seja, significaria facilitar um investimento no capital humano (preparação dos colaboradores em áreas técnicas, científicas e, principalmente, buscar por especialialistas para apoiar o desenvolvimento de tal conscientização, de desenvolvimento de trabalhos).

Em relação a questão $n^{\circ} 4$, a qual trata da clientela do $B B$, os gerentes informaram que a prática de gestão ambiental possui uma importância grande para os clientes são $56 \%$. $40 \%$ dos entrevistados declararam que a prática gestão ambiental tem pouca importância para os clientes. E, somente $4 \%$ acreditam que tais projetos não são importantes para a clientela (Gráfico 4).

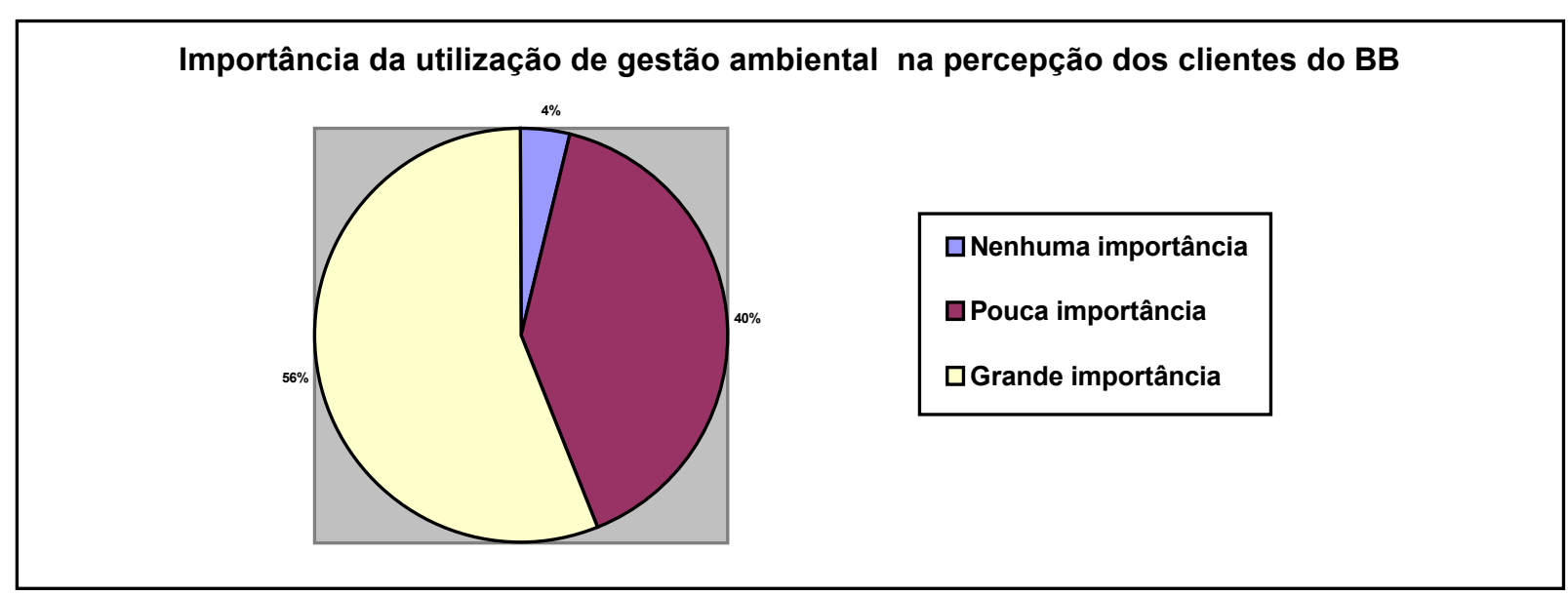

Gráfico 4 Importância da utilização de gestão ambiental na percepção dos clientes do BB

Segundo Weler (2007), o público que mais tem provocado o repensar das empresas nesse contexto ambiental é o consumidor, um segmento de público do qual a empresa depende diretamente para garantir sua sobrevivência. O perfil de um consumidor mais consciente e exigente, principalmente no que se refere aos impactos sociais e ambientais ainda é mais reconhecido em países desenvolvidos, onde a postura de empresa-cidadã já não é novidade. 
Assim sendo, as empresas devem estar preparadas para contar com a flexibilidade necessária para adaptarem-se às exigências de um mercado competitivo, globalizado e que cobra qualidade, ética e responsabilidade social.

As atividades diretas dos bancos, em geral, não produzem resíduos tóxicos poluidores da biosfera. Limitam-se ao consumo de papel, cartuchos de impressão, água, energia elétrica e produção de lixo inorgânico, os quais podem ser reciclados, reutilizados ou economizados.

Questionar sobre as ações práticas de gestão ambiental e sustentabilidade desenvolvidas nas agências entrevistadas, permitiu verificar, conforme Gráfico 5, que $76 \%$ das agências possuem alguma prática implantada de gerenciamento no uso do material de impressão, $46 \%$ possuem programa de reciclagem de papel e $48 \%$ gerenciam a quantidade de papel utilizado no trabalho. As agências que realizam um gerenciamento no consumo de energia pela dependência são $44 \%$ das entrevistadas. Com relação os consumo de água pelos funcionários da agência, $60 \%$ das agências possuem torneiras com mecanismos tecnológicos de racionalização no consumo da água. E, por fim, apenas $24 \%$ das filiais entrevistadas possuem lixeiras próprias para coleta seletiva dos resíduos sólidos descartados pelos funcionários da agência.

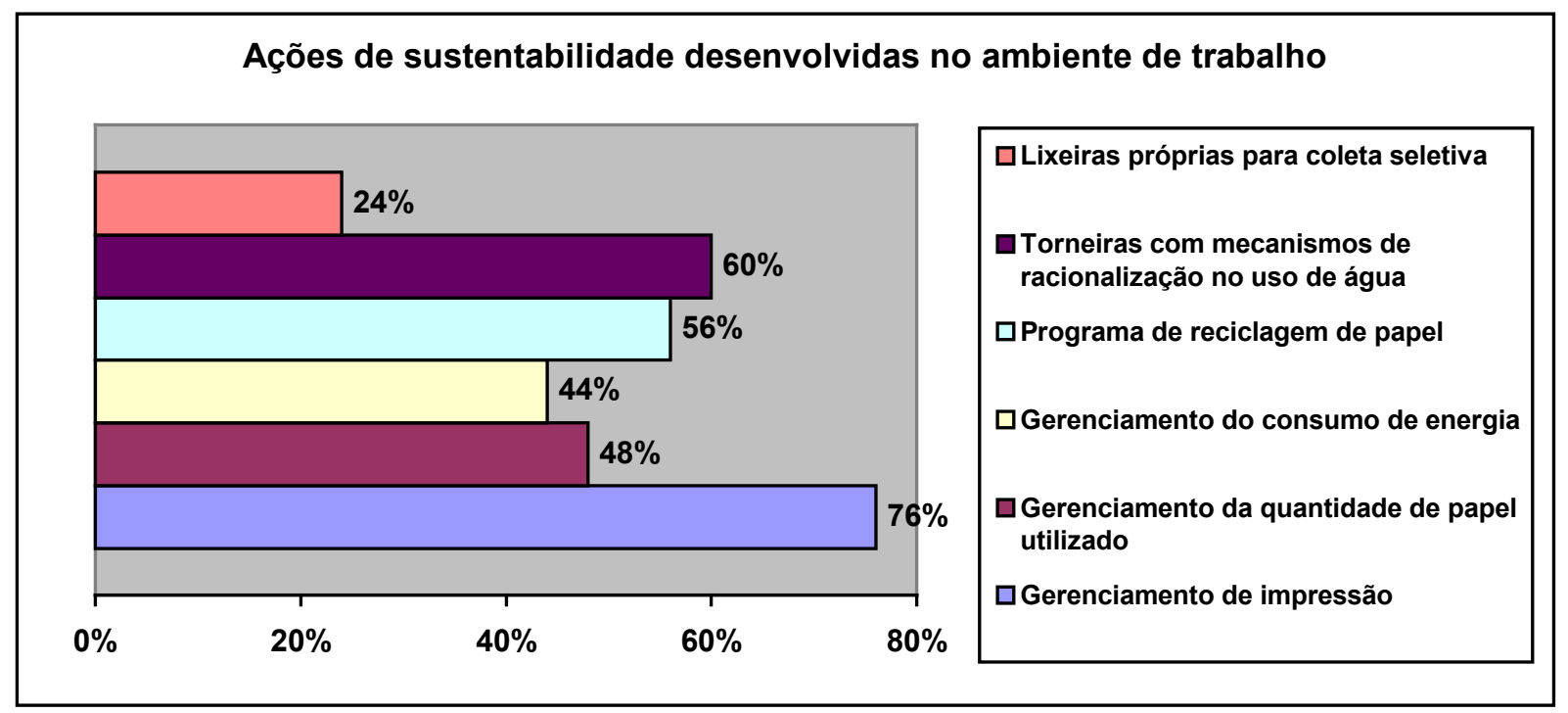

Gráfico 5 Ações de sustentabilidade desenvolvidas no ambiente de trabalho 


\section{CONCLUSÕES E RECOMENDAÇÕES}

Hoje, o mercado é cada vez mais competitivo frente as grandes tecnologias, abertura de fronteiras, quebra de monopólios comerciais, globalização e outras descobertas na ciência mercadológica; esse quadro promove uma concorrência entre empresas, antes não vista, fazendo com que o Mercado venha a buscar por formas de se adequar às novas exigências para sua sobrevivência.

Uma das formas de adequação e sobrevivência no Mercado - exigente -, é o posicionamento ético das Empresas que, com tal postura, melhoram sua imagem pública gradativamente alcançando maior legitimidade social. Aí têm-se o fenômeno da Responsabilidade Social e Gestão Ambiental das empresas. Responsabilidade Social e Ambiental está justamente no limite da compreensão de que a ação das empresas deve, necessariamente, buscar trazer benefícios para a sociedade, propiciar a realização profissional dos empregados e promover benefícios para os parceiros e para o meio ambiente (BOGER, 2005).

O Grupo RSA surgiu da necessidade aprimorar as ações sociais e ambientais do Banco do Brasil. As ações do BB por meio do RSA tem estabelecido processos que permitem garantir o encaminhamento ambientalmente correto dos resultados de produtos e serviços oferecidos pelo BB. Contudo, vale saber até em que nível os colaboradores/funcionários do BB estão integrados em tais projetos e o quanto utiliza do grande potencial que proporcionam para a imagem social da empresa como oportunidade mercadológica para a organização, considerando-os como fatores que contribuem para a obtenção de vantagem competitiva.

Daí, a pesquisa que trouxe como resultado, que a visão de sustentabilidade ambiental dos funcionários do BB que trabalham em agências vinculadas à Superintendência do Distrito Federal, regional Brasília é contraditória visto que ao mesmo tempo em que declaram não ter conhecimento e nem participar das ações desenvolvidas pelo BB em termos de práticas ambientais, eles informam ser muitos importantes essas ações tanto para os clientes como para seus próprios ambientes de trabalho.

Nesse sentido, pode-se afirmar que, de certa forma, as agências investigadas possuem ações ambientalmente sustentáveis implementadas, sendo 
que a grande parte dessas ações estão relacionadas com o monitoramento dos insumos utilizados nos processos de impressão ou utilização de papel. As ações relacionadas à racionalização no uso da água e à destinação dos resíduos sólidos ainda são pequenas se for levado em consideração a quantidade de agências do BB.

Por outro lado, pode-se apontar que as ações implementadas não estão totalmente alinhadas com as estratégias da empresa em termos de políticas ambientais. Ou seja, segundo o BB, os princípios de responsabilidade socioambiental permeiam as políticas e a estratégia corporativa do Banco do Brasil são parte integrante do discurso e do processo de tomada de decisão de todas as áreas do BB, porém, na prática não é esse o resultado apurado nessa pesquisa.

Para a WBCSD (2001), os bancos podem incrementar sua vantagem competitiva e diferenciar-se dos concorrentes com a eco-eficiência. Para isso, devem: (a) integrar o tema ambiental em suas estratégias empresariais; (b) atentarse como os consumidores valorizam e percebem as qualidades ambientais dos produtos e serviços; (c) apreciar as propostas de investimentos ambientais com a mesma importância dos demais investimentos; (d) aumentar a eficiência energética e das matérias-primas por unidade produzida ou por serviço disponibilizado; (e) reduzir os impactos negativos no ecossistema; (f) reutilizar ou reciclar materiais e, (g) reduzir o custo do crédito ao tomador que exercita práticas sustentáveis. Ao manifestar os elementos da ecoeficiência, os bancos geram valor aos seus stakeholders mediante o reconhecimento da gestão pró-ativa dos riscos, da qualidade da administração do negócio e da identificação de novas oportunidades comerciais.

Como limitação, a pesquisa restringiu-se à apuração in loco das realizações sustentáveis de um pequeno grupo de agências representativas da região do DF, prescindindo de melhor verificação. Outrossim, foram consideradas as divulgações nos sítios corporativos e em outras mídias publicitárias, caracterizadas pelo dinamismo e pela constante atualização de conteúdo. Para investigações posteriores, recomenda-se a ampliação da amostra, selecionando as demais agências de varejo do BB, inclusive de outros estados, bem como, a incorporação de outros meios de comunicação. 
Enfim, pode-se dizer, que o BB vem trabalhando para divulgar que é uma empresa que busca conscientizar os funcionários e fazer com que possam participar mais efetivamente das ações sociais e ambientais - propostas e articulas pelo Grupo RSA do BB; que na promoção desta maior conscientização, da empresa as ações sociais e ambientais tem uma maior efetivação, com maiores e melhores resultados. Desta forma, o BB estará desenvolvendo $\square$ mecanismos para que os seus funcionários promovam uma maior divulgação de suas ações de natureza social e ambiental perante seus clientes e a própria sociedade, como uma empresa com ações responsáveis.

Pesquisas mostram que a sociedade procura empresas que possam dar algo em troca para ela. Portanto, o que é desenvolvido para a melhoria da sociedade e do próprio meio ambiente pode ser utilizado como uma ferramenta de marketing, para que cada vez mais ações sociais e ambientais possam ser implementadas. Todas essas ações permitem que o BB seja uma organização de novas tendências em direção a uma diferenciação social, tanto no que se refere na responsabilidade social como na gestão ambiental.

As empresas devem buscar a melhoria para a qualidade de vida da sociedade, sendo que desta forma estará ao mesmo tempo investindo em sua própria organização, através de novos relacionamentos, envolvimentos dos stakeholders, emu ma promoção do marketing social. Ao desenvolver seu marketing social, e mostrar todos os investimentos aplicados em certificações, implantações de normas, implantações de sistemas de gerenciamentos ambientais e de resíduos, o BB estará gerando uma imagem positiva da empresa perante o seu público e a sociedade.

Suas 'pequenas ações' podem representar como 'grandes' para a sociedade e refletir diretamente em seus próprios resultados. 


\section{REFERÊNCIAS}

AGÊNCIA PORTHIA. Comunicação Sócio Ambiental Evento Sustentável. 2008. Disponível em: < http://www.slideshare.net/Camilete/comunicao-scioambientalevento-sustentvel > Acesso em: 2.12.2010.

ANTUNES, P.B. Rio+10: iniciativa energética. 2003. Disponível em: < http://www.amaerj.org.br/ > Acesso em: 5.dez.2010.

ASHLEY, Patrícia Almeida; LIMA, Paulo Rogério dos Santos, FERREIRA, Roberto do Nascimento. Ética e Responsabilidade Social nos negócios. São Paulo: Saraiva, 2 Ed. 2005.

AZEVEDO, Ana Luísa Vieira de. Indicadores de sustentabilidade empresarial no Brasil: uma avaliação do Relatório do CEBDS. Revista Iberoamericana de Economía Ecológica Vol. 5: 75-93, 2006. Disponível em http://www.redibec.org/IVO/rev5 06.pdf. Acesso em 12 Nov 2010

BANCO DO BRASIL. Relatório Anual e de Responsabilidade Socioambiental de 2009. Disponível em http://www45.bb.com.br/docs/ri/ra2009/index.html. Acesso em 20 Jun 2010.

BEZERRA, M.C.L. \& BURSZTIYN, M. Ciência e Tecnologia para o Desenvolvimento Sustentável. Brasília: MMA; IBAMA; Consórcio CDS/UnB/Abipti, 2000.

BOGER, Guilherme. Gestão ambiental e Responsabilidade social: um estudo de caso na empresa Dpaschoal filial Unuguaiana. 2005. Disponível em: < http://br.monografias.com/trabalhos/gestao-ambiental/gestao-ambiental.shtml > Acesso em: 2.12.2010.

BURSZTIYN, M. Para Pensar o Desenvolvimento Sustentável. São Paulo: Brasiliense, 1993.

CLACDS (CENTRO LATINOAMERICANO PARA LA COMPETITIVIDAD Y EL DESARROLLO SOSTENIBLE). Guía de Ecoeficiencia para el Sector Financiero Latinoamericano. Disponível em http://www.ecobanking.com/ES/ecoeficiencia/ . Acesso em 11 Nov 2010. 
CMMAD - COMISSÃO MUNDIAL SOBRE MEIO AMBIENTE E DESENVOLVIMENTO. Nosso Futuro Comum. Rio de Janeiro: FGV, 1988.

COSTA, Carlos Aníbal Nogueira. Em busca do futuro: a competitividade no Brasil. Rio de Janeiro: Campos, 1999.

COSTA, Ana Carolina Ribeiro; PEREIRA, André Beckman; CAMELO, Gerda Lúcia Pinheiro. Sustentabilidade como estratégia de desenvolvimento: a

nova tendência do mercado internacional. In: II Congresso de Pesquisa e Inovação da Rede Norte Nordeste de Educação Tecnológica. João Pessoa, 2007.

Disponível

http://www.redenet.edu.br/publicacoes/arquivos/20071227 160158 GEST-031.pdf

Acesso em 11 Nov 2010.

DIAS, G.F. Fundamentos da Educação Ambiental. Brasília: Universa, 2000.

DONAIRE, Denis. A internalização da gestão ambiental na empresa. Revista de Administração USP, São Paulo, v.31, n.1, p. 44-51,1996.

Gestão ambiental na empresa. 2. ed. São Paulo: Atlas, 1999.

EMPRESA RESPONSÁVEL. Catálogos de produtos de menor impacto ambiental. Julho, 2008. Disponível em: < http://www.empresaresponsavel.com/html/acao e responsabilidade social-07.html > Acesso em: 22.Nov.2010.

FARIA,D.S. Ensino de Ciências Através da Educação Ambiental Científica Tecnológica. Vol.1 Brasília: UnB, FE; UnB, ICB; MEC-CAPES, SPEC-PADCT, 1997.

FARIAS, Josivânia Silva; TEIXEIRA, Rivanda Meira. A pequena e Micro Empresa e - Meio Ambiente: a percepção dos empresários com relação aos impactos ambientais. Revista Organizações \& Sociedade. V. 9, nr 23, p. 99-114. Salvador, 2002. Disponível em http://www.revistaoes.ufba.br/viewarticle.php?id=90 Acesso em 11 Nov 2010.

FEBRABAN (FEDERAÇÃO BRASILEIRA DOS BANCOS). Balanço Social dos Bancos 2003. Disponível em http://www.febraban.org.br/p5a 52gt34++5cv8 4466+ff145afbb52ffrtg33fe36455li54 $11 \mathrm{pp}+\mathrm{e} / \mathrm{sitefebraban/balanco}$ Social 2003.pdf. Acesso em 25 Jun 2010. 
FÉLIX, Joana d'Arc Bicalho. Comunicação e Movimento Ambiental. In: FÉLIX, Joana D'Arc Bicalho \& BORDA, Gilson Zehetmeyer (orgs.). Gestão da Comunicação e Responsabilidade Socioambiental. Uma Nova Visão de Marketing e Comunicação para o Desenvolvimento Sustentável. São Paulo: Atlas, 2009.

Impacto do Desenvolvimento Econômico sobre o Meio Ambiente. Empresa e Impacto Ambiental. Setembro/2008. Disponível em: < http://www.empresaresponsavel.com/html/pag empresa09.html $>$ Acesso em: 22.nov.2010.

GARNIER, Cecília de Assis. Responsabilidade social e ambiental da empresa. Centro Nacional de Educação à Distância - CENED. 2009. Disponível em: < http://www.cenedcursos.com.br/responsabilidade-social-e-ambiental-daempresa.html > Acesso em: 2.12.2010.

INSTITUTO ETHOS. O que as empresas podem fazer pela erradicação da probeza. Disponível em http://www.ethos.org.br/ Uniethos/Documents/manual pobreza .pdf Acesso em 20 Jun 2010.

KRAEMER, Maria Elisabeth Pereira. Gestão Ambiental: Um Enfoque no Desenvolvimento Sustentável, 2004. Disponível em http://www.gestaoambiental.com.br/recebidos/maria kraemer pdf/GEST\%C30\%20A MBIENTAL\%20UM\%20ENFOQUE\%20NO\%20DESENVOLVIMENTO\%20SUSTENT \%C1VEL.pdf Acesso em 11 Nov 2010.

MATA CILIAR. Empresas adotam áreas verdes. Disponível em: < http://www.mataciliar.pr.gov.br/modules/noticias/article.php?storyid=1553 > Acesso em: 22.nov.2010.

PEDRINI, Alexandre de Gusmão. (org.) Educação Ambiental: reflexões e práticas contemporâneas. 4.ed. Petrópolis, RJ: Vozes, 1997.

PERCEPÇÃO NO AMBIENTE ORGANIZACIONAL. Disponível em: < http://sobrepercepcao.blogspot.com/ > Acesso em: 22.11.2010.

PINTO, Isabela Raposo; LELIS, Michelle Gomes; MAGALHÃES, Ráisla Raiani Moreira; LINHARES, Adriana Mayrink. Inclusão Social e Responsabilidade Ambiental Empresarial - Avisão de Empresários e Clientes quanto ao Uso de Sacolas Plásticas, em dois Supermercados de Viçosa - MG. 2008. Disponível em:

http://www.sociedadeinclusiva.pucminas.br/Vseminario/Anais V Seminario/meio/co 
mu/INCLUSAO $\% 20$ SOCIAL $\% 20$ E $\% 20$ RESPONSABILIDADE $\% 20 A M B I E N T A L \% 20 E$ MPRESARIAL $\% 20-$

\%20A\%20VISAO $\% 20$ DE $\% 20$ EMPRESARIOS $\% 20$ E $\% 20$ CLIENTES $\% 20 Q U A N T O \% 2$ 0AO\%20USO \%20DE\%20SACOLAS\%20PLASTICAS.pdf > Acesso em: 20.nov.2010

RODRIGUES, Vivian. Índice Mundial de Sustentabilidade Dow Jones. Responsabilidade Sócioambiental. Disponível em: < http://www.dialogosuniversitarios.com.br/pagina.php?id=2701 > Acesso em: $20 . n o v .2010$.

SANTOS JUNIOR, Humberto Adami. A Responsabilidade Ambiental dos Bancos. Disponível em http://www.ibap.org/direitoambiental/artigos/ha.htm Acesso em 20 Jun 2010.

SANTOS, Mário Augustos dos. Empresas, Meio Ambiente e Responsabilidade Social: um olhar sobre o Rio de Janeiro. Rio de Janeiro: UFRJ, 2003. Disponível em

http://www.ie.ufrj.br/gema/pdfs/empresas meio ambiente e responsabilidade socia um olhar sobre o rio de janeiro.pdf Acesso em 11 Nov 2010.

SANTOS, Patrick Michel Finazzi; FINAZZI, Silvia Vieira Marques. Análise do Discurso Ambiental dos Bancos Brasileiros de Varejo cujas Ações são Negociadas na Bovespa. In: IV Encontro Nacional da Anppas. Brasília, 2008. Disponível em http://www.anppas.org.br/encontro4/cd/ARQUIVOS/GT10-315-61820080510222411.pdf Acesso em 11 Nov 2010.

SAVITZ, Andrew W. e WEBER, Karl. A Empresa Sustentável: o verdadeiro sucesso é o lucro com responsabilidade social e ambiental. [trad. Afonso Celso da Cunha Serra]. Rio de Janeiro: Elsevier, 2007.

TACHIAZAWA, Takeshy. Gestão ambiental e responsabilidade social corporativa: estratégias de negócios focadas na realidade brasileira. São Paulo: Atlas, 2002.

VIRTUOSO, José Carlos. Desenvolvimento, Gestão Ambiental e Sustentabilidade: compreendendo o novo paradigma. Disponível em http://www.espacoacademico.com.br/038/38cvirtuoso.htm . Acesso em 20 jun 2010.

ZANELLA, L. C. H. Metodologia da pesquisa. Apostila elaborada para o curso de administração na modalidade a distância. Brasília: UnB, 2009. 
WBCSD (WORLD BUSINESS COUNCIL FOR SUSTAINABLE DEVELOPMENT). A eco-eficiência: criar mais valor com menos impacto. Lisboa: World Business Council for Sustainable Development, 2001. Disponível em http://www.wbcsd.org/web/publications/eco efficiency creating more valueportuguese.pdf Acesso em 08.nov.2010

WELER. Wanderlei. Consciência da gestão ambiental e os benefícios decorrentes do marketing ambiental: a percepção das empresas clientes do Banco do Brasil. Porto Alegre: UFRS, 2007. Disponível em http://www.lume.ufrgs.br/bitstream/handle/10183/14215/000649503.pdf?sequence=1 Acesso 11.nov.2010.

WORLD BANK. Who Cares, Wins: Connecting the Financial Markets to a Changing World, Investiment Financial Corporation. 2004. Disponível em: < www.unglobalcompact.org/issues/financial-markets/who-cares-who-wins.pdf > Acesso em: 24.nov.2010. 


\section{Anexo A - Instrumento de Pesquisa}

1) Qual é o nível de conhecimento sobre os projetos de gestão ambiental desenvolvidos pelo BB?

( ) Nenhum conhecimento sobre o tema

( ) Pouco conhecimento sobre o tema

( ) Grande conhecimento sobre o tema

2) Qual é o seu grau de envolvimento com os projetos de gestão ambiental que o BB possui?

( ) Nenhum envolvimento com os temas

( ) Pouco envolvimento com os temas

( ) Grande envolvimento com os temas

3) Na sua opinião, referente aos projetos de gestão ambiental desenvolvidos pelo BB, qual o nível da importância destes no seu trabalho diário?

( ) Nenhuma importância no meu trabalho diário.

( ) Pouca importância no meu trabalho diário.

( ) Grande importância no meu trabalho diário.

4) Na sua opinião, qual o nível de importância, da utilização de gestão ambiental em relação aos clientes do Banco do Brasil:

( ) Nenhuma importância

( ) Pouca importância

( ) Grande importância

5) Marque as ações de sustentabilidade que são desenvolvidas em seu ambiente de trabalho:

( ) Gerenciamento de impressão

( ) Gerenciamento da quantidade de papel utilizado

( ) Gerenciamento do consumo de energia

( ) Programa de reciclagem de papel

( ) Torneiras com mecanismos de racionalização no uso de água

( ) Lixeiras próprias para coleta seletiva 